\title{
Influence of plastic film mulch with biochar application on crop yield, evapotranspiration, and water use efficiency in northern China; A meta-analysis
}

\author{
Erastus Mak-Mensah ${ }^{1}$, Peter Bilson Obour ${ }^{2}$, Eunice Essel $^{3}$, Qi Wang ${ }^{\text {Corresp., } 1}{ }^{\text {, Kojo Ahiakpa }}{ }^{4}$ \\ ${ }^{1}$ College of Grassland Science, Gansu Agricultural University, Lanzhou, Gansu Province, China \\ 2 Department of Geography and Resource Development, University of Ghana, Accra, Greater Accra, Ghana \\ 3 Department of Applied Biology, University for Development Studies, Tamale, Northern region, Ghana \\ 4 Research Desk Consulting Ltd, Accra, Ghana \\ Corresponding Author: Qi Wang \\ Email address: 2873527446@qq.com
}

Background. China is the leading consumer of plastic film worldwide. Plastic film mulched ridge-furrow is one of the most widely adopted agronomic and field management practices in rain-fed agriculture in dry-land areas of China. The efficiency of plastic film mulching as a viable method to decrease evapotranspiration (ET), increase crop yields, and water use efficiency (WUE), has been demonstrated extensively by countless experiments.

Methods. A comprehensive evaluation of how co-application of plastic-film mulch and biochar in different agro-environments under varying climatic conditions influence ET, crop yield, WUE, and soil microbial activity were assessed. We performed a meta-analysis using the PRISMA guideline to assess the effect of plastic-film mulched ridge-furrow and biochar on ET, yield, and WUE of wheat (Triticum aestivum L.), potato (Solanum tuberosum L.), and maize (Zea mays L.) in northern China.

Results. The use of plastic film increasedmean yields of wheat (75.7\%), potato (20.2 \%), and maize (12.9\%) in Gansu, Ningxia, Shaanxi, and Shanxi provinces, respectively due to the reduction in ET by 12.8 \% in Gansu, 0.5 \% in Ningxia, and $4.1 \%$ in Shanxi, but increased in Shaanxi by $0.5 \%$ compared to no-mulching. These changes may also be attributed to the effect of plastic film mulch application which simultaneously increased WUE by $68.5 \%$ in Gansu, $23.9 \%$ in Ningxia, $16.2 \%$ in Shaanxi, and $12.8 \%$ in Shanxi, respectively. Compared to flat planting without mulching, in three years, the yield of maize increased with the co-application of plastic film and biochar by $22.86 \%$ in the Shanxi and Shaanxi regions.

Conclusion. Our analysis revealed co-application of plastic film with biochar is integral for improving soil and water conservation in rain-fed agriculture and as an integrated practice to avert drought while simultaneously mitigating runoff and erosion. 


\title{
Influence of plastic film mulch and biochar application on crop yield, evapotranspiration, and water use efficiency in northern China: A meta- analysis
}

\author{
Erastus Mak-Mensah ${ }^{1}$, Peter Bilson Obour ${ }^{2}$, Eunice Essel $^{3}$, Qi Wang ${ }^{1 *}$, Kojo Ahiakpa $^{4}$ \\ ${ }^{1}$ College of Grassland Science, Gansu Agricultural University, Lanzhou, China \\ 2 Department of Geography and Resource Development, University of Ghana, Accra, Ghana \\ ${ }^{3}$ Department of Applied Biology, University for Development Studies, Tamale, Ghana \\ ${ }^{4}$ Research Desk Consulting Ltd, Accra, Ghana
}

Correspondence: Qi Wang ${ }^{1}$, Number 1 Yingmen Road, Anning District, Lanzhou, Gansu Province, China. Email address: 2873527446@qq.com.

\begin{abstract}
Background. China is the leading consumer of plastic film worldwide. Plastic film mulched ridge-furrow is one of the most widely adopted agronomic and field management practices in rain-fed agriculture in dry-land areas of China. The efficiency of plastic film mulching as a viable method to decrease evapotranspiration (ET), increase crop yields, and water use efficiency (WUE) has been demonstrated extensively by countless studies in recent past.
\end{abstract}

Methods. A comprehensive evaluation of how co-application of plastic-film mulch and biochar in different agro-environments under varying climatic conditions influence ET, crop yield, WUE, and soil microbial activity were assessed. We performed a meta-analysis using the PRISMA guideline to assess the effect of plastic-film mulched ridge-furrow and biochar on ET, yield, and WUE of wheat (Triticum aestivum L.), potato (Solanum tuberosum L.), and maize (Zea mays L.) in northern China.

Results. The use of plastic film increased mean yields of wheat $(75.7 \%)$, potato $(20.2 \%)$, and maize $(12.9 \%)$ in Gansu, Ningxia, Shaanxi, and Shanxi provinces, respectively due to the reduction in ET by $12.8 \%$ in Gansu, $0.5 \%$ in Ningxia, and $4.1 \%$ in Shanxi, but increased in Shaanxi by $0.5 \%$ compared to no-mulching. These changes may also be attributed to the effect of plastic film mulch application which simultaneously increased WUE by $68.5 \%$ in Gansu, $23.9 \%$ in Ningxia, $16.2 \%$ in Shaanxi, and $12.8 \%$ in Shanxi, respectively. Compared to flat planting without mulching, in three years, the yield of maize increased with the co-application of plastic film and biochar by $22.86 \%$ in the Shanxi and Shaanxi regions. 
38

39

40

41

42

43

44

45

46

47

48

49

50

51

52

53

54

55

56

57

58

59

60

61

62

63

64

65

66

67

68

69

70

71

72

73

74

75

76

77

Conclusion. Our analysis revealed co-application of plastic film with biochar is integral for improving soil and water conservation in rain-fed agriculture and as an integrated practice to avert severe effect of drought while simultaneously mitigating runoff and erosion.

\section{Introduction}

Poor soil fertility and water scarcity pose a major threat to crop production to meet the food needs of the increasing global population (Qin et al., 2015). Soil water conservation has been identified as an important strategy for enhancing crop productivity in rain-fed agriculture (Ding et al., 2018). The amount of soil water and nutrient during different growing seasons have marked impact on crop yields in rain-fed agriculture, especially in semi-arid regions with rapidly changing climate (Grassini et al., 2010). Unfortunately, most soils in rain-fed farming areas are nutrient-deficient and susceptible to soil erosion and runoff (Liu et al., 2009). Thus, soil as an important natural asset should be properly managed to ensure sustainable development (Panpatte \& Jhala, 2019). Appropriate land and water management practices are required to reduce the risk of widespread water resource depletion in dry agricultural areas (Chang \& Liu et al., 2014). For instance, Olsovska et al., (2016) reported drought-induced accelerated leaf diffusion resistance against carbon dioxide $\left(\mathrm{CO}_{2}\left(\mathrm{~g}_{\mathrm{m}}\right)\right)$ flow resulting in decreased stomatal conductance $\left(\mathrm{g}_{\mathrm{s}}\right)$, leaf mesophyll conductance for $\mathrm{CO}_{2}$, and net $\mathrm{CO}_{2}$ assimilation rate $\left(\mathrm{A}_{\mathrm{N}}\right)$ in wheat. Hence, rain-fed crop production and management practices need to be optimized to provide more resilient options to cope with decreasing precipitation and extreme drought periods in these regions (Verhulst et al., 2011).

Soil water conservation by soil mulching has been projected as a feasible approach to overcome water scarcity for crop productivity in rain-fed agricultural areas. Local farmers in the rain-fed agricultural areas of the Loess Plateau of China practice ridge-furrow rainwater harvesting with plastic film mulching to improve yield and water use efficiency of crops (Eldoma et al., 2016, Yu et al., 2018, Zhang et al., 2018, Pan et al., 2019). Mulching offers significant agro-ecological potential (Erenstein, 2003) and thus, one of the important agronomic practices to improve moisture retention capacity of soils (Ye \& Liu, 2012), promotes carbon dioxide $\left(\mathrm{CO}_{2}\right)$ retention in leaves (Samui et al., 2020), soil microbial characteristics, and crop nutrients assimilation (Chakraborty et al., 2008). In unproductive soils, plastic film mulching also promotes nutrient use efficiency. For instance, Mondal et al. (2020) demonstrated $50 \%$ of the recommended dose of nitrogen with no rhizobium resulted in maximum nitrogen use efficiency while under polythene mulch; significant root nodules were recorded for treatments that received $75 \%$ of the recommended dose of nitrogen with rhizobium inoculation.

Plastic film mulch reduces evapotranspiration and enhances plant growth (Qin et al., 2015, Shen et al., 2019). Plastic mulches usually leave residues in fields they have previously been applied (Jabran, 2019). The residual effect of plastic mulching can considerably increase yields, and water use efficiencies of Triticum aestivum L. and Zea mays L. (Qin et al., 2015) while reducing evapotranspiration (ET) (Fan et al., 2017). Contrarily, ET increased by 38.1 and $9.3 \%$ in plastic film mulched ridge-furrow and flat-planted non-mulched maize fields, respectively 
78 (Gong et al., 2017). In the first and second seasons with plastic film mulching and flat planting 79 with no mulching areas, Mbah and Nwite, (2010) recorded an increment in yield from 55-78 and 80 108-142\%. In two consecutive growing seasons in China, plastic film mulching with biochar 81 modification increased the root and shoot biomass and grain yield of maize (Xiao et al., 2016). 82 Although plastic film mulching has been the ultimate choice of mulching material in rain-fed 83 areas, to enhance water availability in the soil for plant growth (Zhang et al., 2017), it equally 84 poses a challenge of residual plastic film on farmlands which can impede soil structure, plant 85 growth, nutrients and water uptake (Liu et al., 2014). The persistence of residuals in soils from 86 pesticides (Hüffer et al., 2019) and fertilizers (Anyaoha et al., 2018) pose risks to their

87

88

89

90

91

92

93

94

95

96

97

98

99

100

101

102

103

104

105

106

107

108

109

110

111

112

113

114

115

continuous use as inputs in agriculture. Consequently, biochar applications with plastic film mulching have been touted as an effective agronomic practice to mitigate the negative effects of residual plastic film mulching under field conditions. However, studies on the co-application of biochar and plastic film mulches in China are limited (Aller et al., 2018).

Biochar is a carbon-rich product of the thermo-chemical conversion of organic material used as a soil amendment due to its gradual decomposition rate and influence on nutrient dynamics (Gao et al., 2019). The focus of biochar research has advanced from its effects on semi-arid soils to its potential as a soil management material for global agriculture (Wimmer et al., 2013). In arid areas, biochar application improves soil water adsorption capacity, fertility, microbial activity, organic matter content, soil porosity, water retention, soil quality, soil aeration, and nutrients uptake for enhanced crop production (Yang \& Ali, 2018). Biochar has appreciable carbon sequestration value and may act as a modifier or carbon sink to reduce $\mathrm{CO}_{2}$ emissions from decaying biomass, nutrient leaching, soil bulk density, erosion, or fertilizer needs (Mohan et al., 2014, Kavitha et al., 2018). The shared impact of plastic film mulching with biochar on ET, crop yield, and WUE as a ridge-furrow rainwater harvesting technology in China are currently less understood (Nelissen et al., 2012, Fischer et al., 2019). Therefore, understanding how biomass in China and across the world can change under the combined application of plastic film and biochar and processes activated as a result of these changes is key to harnessing their potential for wider use in agriculture (Antala et al., 2020).

The effects of plastic film mulched ridge-furrow with biochar on ET, crop yield, and WUE in rain-fed agro-ecological areas in China have been reported in the past with mixed results. We, therefore, hypothesized that the co-application of plastic film with biochar in semi-arid regions is an optimum agronomic practice for minimizing the adverse impact of drought while simultaneously mitigating runoff and erosion. Here, we performed a meta-analysis on relevant literature using the PRISMA guideline (Moher et al., 2009) to ascertain the impact of ridgefurrow plastic film mulching with biochar on ET, crop yield, and WUE of maize, wheat, and potato.

\section{Materials \& Methods}

Peer] reviewing PDF | (2020:11:55313:1:1:NEW 1 Jan 2021) 


\section{Data collection}

Data from only peer-reviewed publications in English investigating the effects of plastic film mulching and biochar on field crops from 1990-2020 were retrieved from online databases (ISI Web of Science, Scopus (Elsevier), ScienceDirect, PubMed, JSTOR, and Google Scholar). Nevertheless, articles from conference proceedings were excluded from this meta-analysis. In the databases, 'yield ', and/or 'plastic film ', and/or 'biochar,' and 'mulching' were used as search keywords. Erastus Mak-Mensah and Eunice Essel performed the Search Strategy and independently decided on appropriate publications for the study. Qi Wang intervened and resolved by discussing cases where Erastus Mak-Mensah and Eunice Essel had disagreements on the use of a particular reference in the study. The search produced a total of 556 publications, which were screened based on (1) on-field experimentation containing at least plastic film mulched ridges and no mulch treatments; (2) experimental sites located in rain-fed agriculture areas of China in Gansu, Ningxia, Shaanxi, and Shanxi provinces; (3) colors of the plastic film were black and transparent; (4) the publication included estimates of ET, crop yield, or WUE. Subsequently, due to insufficient and missing data, 535 papers were excluded from this metaanalysis and the final analysis was conducted on 21 studies (papers) based on ET, yields, and WUE after the screening process. The process of screening of publications for the meta-analysis is depicted in a flowchart (Figure 1); which was adapted from the PRISMA protocol (Moher et al., 2009). Farming provinces and locations of field experiments for all the crops in this study are shown in Table 1 and Figure 2. Data within the selected publications were categorized based on estimated biophysical parameters (Table 2). Variations in ET, yield, and WUE of wheat, maize, and potato under plastic film and no-mulching applications were shown in Table 3 while Table 4 shows the mean, range, and coefficient of variation (CV) of ET, yield, and WUE in different locations and precipitations in northern China. The mean, range, and coefficient of variation (CV) of yield of maize for plastic film mulched ridge-furrow and no mulching in Shanxi and Shaanxi provinces in China were shown in Table 5.

\section{Data analysis}

Meta-analysis enables the statistical analysis of effect sizes and quantitative evaluation of experimental outcomes reported by other authors. Meta-analysis enhances the statistical capacity available for testing the hypotheses and the reaction variations between treatments in different environments. Unbiased estimation of the underlying true effect size, subject to random variance, can be assumed to be the effect size observed in each sample. The Newcastle Ottawa Scale (NOS), (Zeng et al., 2015), was used to assess the importance of the papers involved in this study. High-quality publications (papers) were considered based on $\geq 7$ score. The scores for NOS varied from 6 to 9 (Table 1). More weight is given to data from experiments with more reliable measurements because they have a larger effect on the overall calculation ( $\mathrm{Yu}$ et al., 2018).

We used construction confidence interval analysis (Gao et al., 2019) to correlate the severity of the response ratio between the plastic film mulched ridge-furrow and no mulching 
156

157

158

159

160

161

162

163

164

165

166

167

168

169

170

171

172

173

174

175

176

177

178

179

180

181

182

183

184

185

186

187

188

189

190

191

192

193

194

195

treatments. The effect size was computed as the natural $\log (\ln \mathrm{R})$ of the response ratio $(\mathrm{R})(\mathrm{Gao}$ et al., 2019; Qin et al., 2015), which reflects the severity of the effect of plastic film mulch on ET, yield, and WUE in this meta-analysis (Hedges, Gurevitch \& Curtis, 1999), equation 1:

$$
\begin{aligned}
& \mathrm{R}=\theta_{\mathrm{t}} / \theta_{\mathrm{c}} \\
& \operatorname{InR}=\operatorname{In}\left(\theta_{\mathrm{t}} / \theta_{\mathrm{c}}\right)=\operatorname{In} \theta_{\mathrm{t}}-\operatorname{In} \theta_{\mathrm{c}}
\end{aligned}
$$

where $\theta_{\mathrm{t}}$ and $\theta_{\mathrm{c}}$ equates the mean values of ET, yield, and WUE in plastic film mulched ridge-furrow and no mulching, respectively. To further authenticate the outcomes from this analysis, the percentage of change (Z) in ET, yield, and WUE were determined according to Li et al. (2018) as:

$$
\mathrm{Z}=(\mathrm{R}-1) \times 100 \%
$$

where a negative value for percentage change shows a decline in the variable with plastic film mulching relative to no mulching and a positive value for percentage change, indicates an enhancement in the matching variable for plastic film mulching relative to no-mulching. Conversely, the sample sizes of the variables and standard deviation (SD) involved were obtained in addition to the means from the articles or computed using the following equation ( $\mathrm{Yu}$ et al., 2018):

$$
\mathrm{SD}=\mathrm{SE} \times \sqrt{ } \mathrm{n}
$$

For studies which did not report the SD; the average coefficient of variation (CV) within each data was computed and then approximated the unavailable SD using the following equation (Yu et al., 2018):

$$
\mathrm{SD}=\mathrm{CV} \times \theta
$$

where $\theta$ equates the mean of plastic film mulched ridge-furrow with biochar or no mulching. The effect sizes of plastic film with biochar and no-mulching for ET, crop yield, and WUE were continuous variables, hence were calculated by random-effects models using the Review Manager software (RevMan; ver. 5.3, Nordic Cochrane Centre, Denmark). The heterogeneity between studies used in this analysis has been measured with $\mathrm{Chi}^{2}$ and $\mathrm{I}^{2}$ statistics (Table 6). The parameters for heterogeneity for the $\mathrm{I}^{2}$ test were as follows: $\mathrm{I}^{2}<25 \%$ indicates no heterogeneity; moderate heterogeneity is considered to be $25-75 \%$; strong heterogeneity is considered to be $\mathrm{I}^{2}>75 \%$ (Table 7). Random-effects models were implemented in cases of mild to high heterogeneity, indicated by a $\mathrm{Chi}^{2} \mathrm{p}$-value $<0.05$ and $\mathrm{X}^{2}>50 \%$. The RevMan program weighed the mean differences of the plastic film with biochar and no-mulching groups according to their SE and sample sizes, and their confidence intervals (CI) were computed from their weighted effect sizes. The impact of a treatment was significant if there was no zero in the $95 \%$ CIs of the effect size of that treatment. Conversely, the treatment was considered not significant when the $95 \%$ CIs includes zero. Similarly, a general linear model in SPSS statistical software (ver. 26.0, SPSS Inc., Chicago, USA) was used to compute the effect of location, crop type, and rainfall on ET, crop yield, and WUE. The frequency distribution of effect sizes (Odds ratio) was computed using Excel 2016 spreadsheet to illustrate the distribution symmetries of the individual studies. 
196

197

198

199

200

201

202

203

204

205

206

207

208

209

210

211

212

213

214

215

216

217

218

219

220

221

222

223

224

225

226

227

228

229

230

231

232

233

234

\section{Results}

Yield response of wheat, maize, and potato in different locations and climate

Considering climate variables (precipitation and air temperature), the meta-analysis indicated that in the growing-seasons, precipitation and air temperature had no significant $(\mathrm{p}>$ 0.05 ) effects on maize, wheat, and potato yields in the plastic film mulched ridge-furrow treatment (Figure 1). The meta-analysis dataset had $\mathrm{pH}$ in all the areas of study as slightly alkaline ( $>7$ ) hence no comparison was made in that regard (Table 4). Therefore, we investigated in three categorized soil types, i.e., light, medium, and heavy, the impacts of ridge-furrow plastic film mulching on maize, wheat, and potato yields and (Table 4). In the plastic film mulched ridge-furrow treatment, the mean effect size for the light soil type $(1.68[0.38,2.99])$ was significant $(\mathrm{p}=0.01)$ as compared to the medium and heavy soil types (Figure 3 ). The mean effect size was not significantly $(p>0.05)$ different among the medium and heavy soil types in the plastic film mulched ridge-furrow treatment. Maize yields in Shanxi ranged from 11290 to $11527 \mathrm{~kg} \mathrm{ha}-1$ in the plastic film mulched ridge-furrow treatment and were significantly $(\mathrm{p}<$ 0.05) higher than for Ningxia which ranged from 12779 to $13073 \mathrm{~kg} \mathrm{ha}-1$ in our meta-analysis dataset (Table 3). The impacts of plastic film mulched ridge-furrow on yield varied with the soil bulk density (Table 4). Plastic film mulched ridge-furrow significantly $(p<0.05)$ improved yield in light soils by $43 \%$ compared with flat planting with no mulching in areas with a soil bulk density of $>1.3 \mathrm{~g} \mathrm{~cm}^{-3}$ (Figure 3). Soil organic carbon (SOC) content of $0-10 \mathrm{~cm}$ soil layer in areas of $>9 \mathrm{~g} / \mathrm{kg}$ in the plastic film mulched ridge-furrow treatments, was improved $(27.8 \%)$ compared with flat planting with no mulching. With high soil available $\mathrm{N}(>50 \mathrm{mg} \mathrm{kg}-1)$, plastic mulching exerted a greater impact on maize, wheat, and potato yield with high soil available $\mathrm{P}(>20 \mathrm{mg} \mathrm{kg}-1)$ and low soil available $\mathrm{K}(<150 \mathrm{mg} \mathrm{kg}-1)$.

\section{ET and water use efficiency of wheat, maize, and potato in different locations}

Compared with flat planting without mulching, plastic film mulched ridge-furrow significantly increased WUE $(16.1 \% ; \mathrm{p}=0.01)$ in regions with an air temperature $>9{ }^{\circ} \mathrm{C}$, but, had no significant impact on ET $(0.46 \% ; \mathrm{p}=0.64)$ (Figure 4). This increase in WUE was significant in regions with heavy soil type of soil texture $(20.68 \% ; p=0.01)$, soil organic carbon content of $>9 \mathrm{~g} / \mathrm{kg}(22.2 \% ; \mathrm{p}=0.03)$, and soil available $\mathrm{N}$ of $>50 \mathrm{mg} \mathrm{kg}-1 \quad(22 \% ; \mathrm{p}=0.01)$ (Figure 5). In contrast, plastic film mulched ridge-furrow had no significant effects on ET in heavy soil type $(0.99 \% ; p=0.96)$, soil organic carbon content of $>9 \mathrm{~g} / \mathrm{kg}(1.67 \% ; \mathrm{p}=0.91)$ and soil available $\mathrm{N}$ of $>50 \mathrm{mg} \mathrm{kg}-1(0.51 \% ; \mathrm{p}=0.95)$ (Figure 4). The average WUE of maize in Ningxia was significantly increased by $33.9 \%(\mathrm{p}=0.01)$ with plastic film mulched ridge-furrow higher than $16.2 \%$ in Shaanxi compared to flat planting without mulching (Figure 5). The increase in WUE with plastic film mulched ridge-furrow may be attributed to the increase in yield and decrease in ET, as demonstrated by our analysis.

Peer) reviewing PDF | (2020:11:55313:1:1:NEW 1 Jan 2021) 
235

236

237

238

239

240

241

242

243

244

245

246

247

248

249

250

251

252

253

254

255

256

257

258

259

260

261

262

263

264

265

266

267

268

269

270

271

272

273

Influence of co-application of plastic film mulched ridge-furrow and biochar on yield

In three years, the yield of maize increased significantly with the co-application of plastic film and biochar by $22.86 \%(\mathrm{p}=0.05)$ compared with flat planting without mulching in the Shanxi and Shaanxi regions. Although, in the plastic film mulched ridge-furrow and biochar coapplication treatments, the mean effect size for maize $(0.79[-0.92,2.50] ; \mathrm{p}=0.05)$ was not significant as compared to the flat planting without mulching in these regions. Mean crop yields ranged from $10.43-14.7(\mathrm{t} / \mathrm{ha})(10430-14700 \mathrm{~kg} / \mathrm{ha})$ with plastic film mulched ridge-furrow and biochar combination treatment as compared to $9.11-9.99(\mathrm{t} / \mathrm{ha})(9110-9990 \mathrm{~kg} / \mathrm{ha})$ in the flat planting without mulching (Table 5).

\section{Discussion}

In the Loess Plateau, variability in the amount and distribution of seasonal precipitation is a major source of variation in ET, which includes evaporation from the soil surface and crop transpiration ( $\mathrm{Lu}$ et al., 2014). This meta-analysis indicated the yield of wheat, maize, and potato was increased with plastic film mulching compared with flat planting with no mulching in Gansu, Ningxia, Shaanxi, and Shanxi provinces. This may be ascribed to increased WUE and decreased in ET in the treatment fields. This is consistent with Mbah and Nwite (2010), who reported plastic film mulch boosts maize yield (55-78 \%) in the first and second seasons (108$142 \%$ ) of maize production. Ding et al. (2019) found that with plastic film mulching, soil hydrothermal conditions improved and substantially accelerated the emergence of wheat leaves and tiller growth, resulting in increased spike number and grain yield. Again, transpiration (Zhou et al., 2009), and soil evaporation (Zribi et al., 2015) decreased with the application of plastic film mulch hence maize yield was improved. Thus, plastic film mulching significantly improves crop production and increases resource use efficiency, as a potential soil amendment for sustainable dryland farming (Ding et al., 2019).

Several studies have subsequently shown that plastic film mulching enhances yield and WUE in different crop fields (Anikwe et al., 2007). In this study, plastic film mulching significantly $(\mathrm{p}=0.01)$ increased WUE and decreased ET $(\mathrm{p}>0.05)$ in the low and high areas of rainfall in Gansu, Ningxia, Shaanxi, and Shanxi provinces. In these areas, the decrease in ET improves the quantity of soil water that enhances to plant emergence and maturity. This finding is consistent with a research by Liu et al. (2014), which asserted full-year double ridge-furrow plastic film mulching could increase grain yields of maize $\left(110 \mathrm{~kg} \mathrm{~N} \mathrm{ha}^{-1}\right)$ and conserve soil water during periods of drought. Simulation of soil water and heat flow in ridge cultivation with plastic film mulching on the Chinese Loess Plateau decreased ET where plastic film mulching was less efficient practice for increasing WUE in dryland agriculture (Zhao et al., 2018). Plastic film mulching can provide conducive surroundings for attaining high potato yield (Wang et al., 2019) and facilitating maize grain filling hence maximizing yield (Liu et al., 2016). Consequently, plastic film mulched ridge-furrow approach may serve as a promising agronomic method in arid and semiarid regions to increase potato yield (Qin et al., 2016). 
274

275

276

277

278

279

280

281

282

283

284

285

286

287

288

289

290

291

292

293

294

295

296

297

298

299

300

301

302

303

304

305

306

307

308

309

310

311

312

313

The ridge furrow $(\mathrm{RF})$ rainfall harvesting planting model with $\mathrm{N}: \mathrm{P}$ fertilizer rate $(300: 150$ $\mathrm{kg} \mathrm{ha}^{-1}$ ) significantly increased $(\mathrm{p}<0.05)$ the mean WUE over 2 years by $53 \%$ compared with the traditional flat planting model (Li et al., 2018a). Conversely, Zhang et al., (2019) in a report suggested $50 \mathrm{~cm}$ mulched ridge: $10 \mathrm{~cm}$ bare furrow ridge-plastic film furrow mulching (RFM) system was more effective in increasing maize growth compared to conventional flat planting. This increased maize grain yield and WUE from $43.1 \%$ to $59.2 \%$ and from $38.5 \%$ to $57.4 \%$, respectively. Concurrently, yield, and WUE in a study by Fan et al., (2019) revealed improved grain yield of $20.0 \%$ and $3.45 \mathrm{~kg} \mathrm{ha}^{-1} \mathrm{~mm}^{-1}$ with plastic film mulched ridge-furrow scheme, respectively. Furthermore, Dang et al., (2016) in 2014 discovered plastic film-mulched ridgefurrow (RF) used $17.9 \%$ less water and $33.1 \%$ more WUE than flat planting with no mulching (FP). In 2015, RF showed 56.2\% higher yield, $15.0 \%$ lower water use (ET), and $63.4 \%$ higher WUE than FP, respectively. Zhao et al., (2012) in 2009 and 2010 also reported yields from plastic film mulched fields increased from 33.9-92.5 \% and 62.9-77.8 \%, respectively, relative to FP, and corresponding WUEs increased from 41.4-112.6 \% and 45.9-70.6\%. Compared to traditional flat planting, the average four-year maize yield increased from $1497.1 \mathrm{~kg} \mathrm{ha}^{-1}$ to $2937.3 \mathrm{~kg} \mathrm{ha}^{-1}$ using the ridge and furrow farming method, and the WUE increased from $2.3 \mathrm{~kg}$ $\mathrm{ha}^{-1} \mathrm{~mm}^{-1}$ to $5.1 \mathrm{~kg} \mathrm{ha}^{-1} \mathrm{~mm}^{-1}$ (Ren et al., 2016). Approximately, in a three-year study, Ren et al., (2016) revealed WUE and yield of winter wheat was significantly higher in a $60 \mathrm{~cm}$ ridge with $60 \mathrm{~cm}$ furrow width than in the conventional flat without ridging by $2.39 \mathrm{~kg} / \mathrm{mm} / \mathrm{ha}$, and 405.1 $\mathrm{kg} / \mathrm{ha}(\mathrm{p}<0.05)$. However, with increases in mulch length, both tuber yield and water usage efficiency (WUE) decreased, indicating plastic film mulch required early removal (Wang et al., 2009). The biodegradable mulch from our analysis improved by 64.5-73.1\%, WUE in maize, wheat, and potato compared to FP (Deng et al., 2019). In addition, Xiaoli et al., (2013) in a threeyear field experiment integrating various furrow-applied mulches in maize production under a plastic film mulched ridge and furrow rainwater harvesting (PRFRH) in China's Loess Plateau semi-arid lands revealed a decrease in plastic film with a thickness of $0.08 \mathrm{~mm}$ use. This indicates soil evaporation losses may be minimized by mulching and emphasizes the potential to increase crop sustainability via integrated PRFRH systems in semi-arid areas.

Xiang et al., (2017) in a meta-analysis revealed biochar modifications increased root biomass by $32 \%$, root diameter by $9.9 \%$, root volume by $29 \%$, root tips by $17 \%$, root length by $52 \%$, and surface area by $39 \%$. Plant roots play key roles in plant maturity (Yu et al., 2019). By altering the growth of roots and rhizosphere microbial activities, biochar may accelerate plant growth and nutrient uptake (Lehmann, 2012). Joseph et al. (2010) found plant roots or root hairs enter soils macro-pores filled with water or attach to the surface of biochar, triggering assorted reactions to facilitate absorption of nutrients. Furthermore, the use of biochar by Mensah $\&$ Frimpong (2018) in maize production on acidic soils in Ghana resulted in a substantial increase $(\mathrm{p}<0.01)$ in leaf number, plant height, and stem girth. Agegnehu et al. (2016) established significant correlations in maize grain yield with total biomass, leaf chlorophyll, $\mathrm{N}$ and $\mathrm{P}$ foliar content, soil organic matter, and soil water content as a direct consequence of biochar application compared to control. Liu et al. (2014) in an experiment obtained the highest yield of sweet potato 
314 (53.77\%; $<<0.05)$, which was higher compared to no biochar treatment (control). Liang et al. 315 (2014), following biochar application, obtained $10 \%$ higher grain yield in winter wheat and 316 summer maize than without control (no biochar). Again, Liang et al. (2014) reported an increase 317 in soil $\mathrm{pH}$ with increasing biochar application rates.

318 According to Xiao et al. (2016), 20 and $30 \mathrm{t} /$ ha biochar treatments increased wheat yields by 3199 and $13 \%$ in 2012 and $14 \%$ in 2013 compared to no biochar treatments respectively. Wheat

320

321

322

323

324

325

326

327

328

329

330

331

332

333

334

335

336

337

338

339

340

341

342

343

344

345

346

347

348

349

350

351

352

353 grain yield remarkably improved by 6 and $9 \%$ in 2012 and 2013 with plastic film mulched ridge-furrow with $20 \mathrm{t}$ /ha biochar treatments compared to plastic film mulched ridge-furrow without biochar treatments (Xiao et al., 2016). In addition, Jeffery et al., (2011) in a metaanalysis indicated biochar-treated soils increased crop productivity by a mean of $10 \%(-28 \%$ to $39 \%$ ) compared with plots without mulching. Residual impact of biochar on fertility largely accounted for an increase in crop yield under co-application of plastic film mulched ridge-furrow with biochar treatment (Rehman \& Razzaq, 2017).

\section{Conclusions}

In rain-fed agricultural regions with minimal rainfall in cropping seasons, ridge-furrow mulching with plastic film resulted in improved crop yields and WUE. The co-application of plastic film mulched ridge-furrow with biochar may potentially mitigate the adverse effects of plastic film application including greenhouse gas emissions, and plastic film residue buildup in soils. Our analysis indicates WUE and yield of maize, wheat, and potato in Gansu, Ningxia, Shaanxi, and Shanxi provinces were significantly influenced by the plastic film mulch application compared to control (no mulching) $(\mathrm{p}<0.05)$. Plastic film mulched ridge-furrow approach of farming had a significant $(\mathrm{p}=0.01)$ impact on light soil type compared to the medium and heavy soil types. ET was significantly decreased as compared with FP during the planting seasons. The combined application of plastic film mulch with biochar in these regions improved yield by $22.86 \%$ compared with FP. This may be an ideal agronomic practice that may be employed by smallholder farmers in crop production for optimum yield. The practice may equally serve as a potential soil and water-saving practice in rain-fed agriculture especially in areas with changing climate to minimize the effect of drought while mitigating runoff and erosion. A future study on plastic film mulched ridge-furrow rainwater harvesting system with biochar may assess and provide detailed information on the combined effect of biochar with plastic film on soil physicochemical properties under field conditions.

\section{References}

Agegnehu G, Bass AM, Nelson PN, Bird MI. 2016. Benefits of biochar, compost, and biocharcompost for soil quality, maize yield, and greenhouse gas emissions in a tropical agricultural soil. Science of the Total Environment 543:295-306. DOI: 10.1016/j.scitotenv.2015.11.054.

Aller DM, Archontoulis S V., Zhang W, Sawadgo W, Laird DA, Moore K. 2018. Long term biochar effects on corn yield, soil quality, and profitability in the US Midwest. Field Crops 
354

355

356

357

358

359

360

361

362

363

364

365

366

367

368

369

370

371

372

373

374

375

376

377

378

379

380

381

382

383

384

385

386

387

388

389

390

391

392

393

Research 227:30-40. DOI: 10.1016/j.fcr.2018.07.012.

Anikwe MAN, Mbah CN, Ezeaku PI, Onyia VN. 2007. Tillage and plastic mulch effects on soil properties and growth and yield of cocoyam (Colocasia esculenta) on an ultisol in southeastern Nigeria. Soil and Tillage Research 93:264-272. DOI: 10.1016/j.still.2006.04.007.

Antala M, Sytar O, Rastogi A, Brestic M. 2020. Potential of karrikins as novel plant growth regulators in agriculture. Plants 9:1-13. DOI: 10.3390/plants9010043.

Anyaoha KE, Sakrabani R, Patchigolla K, Mouazen AM. 2018. Critical evaluation of oil palm fresh fruit bunch solid wastes as soil amendments: Prospects and challenges. Resources, Conservation, and Recycling 136:399-409. DOI: 10.1016/j.resconrec.2018.04.022.

Chakraborty D, Nagarajan S, Aggarwal P, Gupta VK, Tomar RK, Garg RN, Sahoo RN, Sarkar A, Chopra UK, Sarma KSS, Kalra N. 2008. Effect of mulching on soil and plant water status, and the growth and yield of wheat (Triticum aestivum L.) in a semi-arid environment. Agricultural Water Management 95:1323-1334. DOI: 10.1016/j.agwat.2008.06.001.

Dang J, Liang W, Wang G, Shi P, Wu D. 2016. A preliminary study of the effects of plastic filmmulched raised beds on soil temperature and crop performance of early-sown short-season spring maize (Zea mays L.) in the North China Plain. Crop Journal. DOI: 10.1016/j.cj.2016.02.002.

Deng L, Yu Y, Zhang H, Wang Q, Yu R. 2019. The Effects of Biodegradable Mulch Film on the Growth, Yield, and Water Use Efficiency of Cotton and Maize in an Arid Region. Sustainability 11:7039. DOI: 10.3390/su11247039.

Ding D, Feng H, Zhao Y, Hill RL, Yan H, Chen H, Hou H, Chu X, Liu J, Wang N, Zhang T, Dong Q. 2019. Effects of continuous plastic mulching on crop growth in a winter wheatsummer maize rotation system on the Loess Plateau of China. Agricultural and Forest Meteorology 271:385-397. DOI: 10.1016/j.agrformet.2019.03.013.

Ding D, Zhao Y, Feng H, Hill RL, Chu X, Zhang T, He J. 2018. Soil water utilization with plastic mulching for a winter wheat-summer maize rotation system on the Loess Plateau of China. Agricultural Water Management 201:246-257. DOI: 10.1016/j.agwat.2017.12.029.

Eldoma IM, Li M, Zhang F, Li F-M. 2016. Alternate or equal ridge-furrow pattern: Which is better for maize production in the rain-fed semi-arid Loess Plateau of China? Field Crops Research 191:131-138. DOI: 10.1016/j.fcr.2016.02.024.

Erenstein O. 2003. Smallholder conservation farming in the tropics and sub-tropics: A guide to the development and dissemination of mulching with crop residues and cover crops. Agriculture, Ecosystems, and Environment 100:17-37. DOI: 10.1016/S01678809(03)00150-6.

Fan Y, Ding R, Kang S, Hao X, Du T, Tong L, Li S. 2017. Plastic mulch decreases available energy and evapotranspiration and improves yield and water use efficiency in an irrigated maize cropland. Agricultural Water Management 179:122-131. DOI: 10.1016/j.agwat.2016.08.019. 
394

395

396

397

398

399

400

401

402

403

404

405

406

407

408

409

410

411

412

413

414

415

416

417

418

419

420

421

422

423

424

425

426

427

428

429

430

431

432

433

Fan T, Wang S, Li Y, Yang X, Li S, Ma M. 2019. Film mulched furrow-ridge water harvesting planting improves agronomic productivity and water use efficiency in Rainfed Areas. Agricultural Water Management 217:1-10. DOI: 10.1016/j.agwat.2019.02.031.

Fischer BMC, Manzoni S, Morillas L, Garcia M, Johnson MS, Lyon SW. 2019. Improving agricultural water use efficiency with biochar - A synthesis of biochar effects on water storage and fluxes across scales. Science of the Total Environment 657:853-862. DOI: 10.1016/j.scitotenv.2018.11.312.

Gao S, DeLuca TH, Cleveland CC. 2019. Biochar additions alter phosphorus and nitrogen availability in agricultural ecosystems: A meta-analysis. Science of the Total Environment 654:463-472. DOI: 10.1016/j.scitotenv.2018.11.124.

Gao H, Yan C, Liu Q, Ding W, Chen B, Li Z. 2019. Effects of plastic mulching and plastic residue on agricultural production: A meta-analysis. Science of The Total Environment 651:484-492. DOI: 10.1016/j.scitotenv.2018.09.105.

Gong D, Mei X, Hao W, Wang H, Caylor KK. 2017. Comparison of ET partitioning and crop coefficients between partial plastic mulched and non-mulched maize fields. Agricultural Water Management 181:23-34. DOI: 10.1016/j.agwat.2016.11.016.

Grassini P, You J, Hubbard KG, Cassman KG. 2010. Soil water recharge in a semi-arid temperate climate of the Central U.S. Great Plains. Agricultural Water Management 97:1063-1069. DOI: 10.1016/j.agwat.2010.02.019.

Hedges L V., Gurevitch J, Curtis PS. 1999. The meta-analysis of response ratios in experimental ecology. Ecology $\quad 80: 1150-1156 . \quad$ DOI: $\quad 10.1890 / 0012-$ 9658(1999)080[1150:TMAORR]2.0.CO;2.

Hüffer T, Metzelder F, Sigmund G, Slawek S, Schmidt TC, Hofmann T. 2019. Polyethylene microplastics influence the transport of organic contaminants in soil. Science of the Total Environment 657:242-247. DOI: 10.1016/j.scitotenv.2018.12.047.

Jabran K. 2019. Role of Mulching in Pest Management and Agricultural Sustainability. Cham: Springer International Publishing. DOI: 10.1007/978-3-030-22301-4.

Jeffery S, Verheijen FGA, van der Velde M, Bastos AC. 2011. A quantitative review of the effects of biochar application to soils on crop productivity using meta-analysis. Agriculture, Ecosystems, and Environment 144:175-187. DOI: 10.1016/j.agee.2011.08.015.

Joseph SD, Camps-Arbestain M, Lin Y, Munroe P, Chia CH, Hook J, Van Zwieten L, Kimber S, Cowie A, Singh BP, Lehmann J, Foidl N, Smernik RJ, Amonette JE. 2010. An investigation into the reactions of biochar in soil. Australian Journal of Soil Research 48:501-515. DOI: 10.1071/SR10009.

Karer, J., Wimmer B, Zehetner, F., Kloss S, Feichtmair S, Kitzler B. 2013. Biochar application to temperate soils - effects on soil fertility and crop yield. Agriculture and Food Science 22:390-403.

Kavitha B, Reddy PVL, Kim B, Lee SS, Pandey SK, Kim KH. 2018. Benefits and limitations of biochar amendment in agricultural soils: A review. Journal of Environmental Management 227:146-154. DOI: 10.1016/j.jenvman.2018.08.082.

Peer) reviewing PDF | (2020:11:55313:1:1:NEW 1 Jan 2021) 
434 Lehmann J. 2012. Biochar for Environmental Management. DOI: 10.4324/9781849770552.

435 Li C, Li Y, Li Y, Fu G. 2018a. Cultivation techniques and nutrient management strategies to 436 improve the productivity of rain-fed maize in semi-arid regions. Agricultural Water 437 Management 210:149-157. DOI: 10.1016/j.agwat.2018.08.014.

438

439

440

441

442

443

444

445

446

447

448

449

450

451

452

453

454

455

456

457

458

459

460

461

462

463

464

465

466

467

468

469

470

471

472

473

Li Q, Li H, Zhang L, Zhang S, Chen Y. 2018b. Mulching improves yield and water-use efficiency of potato cropping in China: A meta-analysis. Field Crops Research 221:50-60. DOI: $10.1016 /$ j.fcr.2018.02.017.

Liang F, Li G tong, Lin Q mei, Zhao X rong. 2014. Crop yield and soil properties in the first 3 years after biochar application to a calcareous soil. Journal of Integrative Agriculture 13:525-532. DOI: 10.1016/S2095-3119(13)60708-X.

Liu Z, Chen X, Jing Y, Li Q, Zhang J, Huang Q. 2014a. Effects of biochar amendment on rapeseed and sweet potato yields and water-stable aggregate in upland red soil. Catena 123:45-51. DOI: 10.1016/j.catena.2014.07.005.

Liu Q, Chen Y, Liu Y, Wen X, Liao Y. 2016. Coupling effects of plastic film mulching and urea types on water use efficiency and grain yield of maize in the Loess Plateau, China. Soil and Tillage Research 157. DOI: 10.1016/j.still.2015.11.003.

Liu EK, He WQ, Yan CR. 2014. "White revolution" to "white pollution" - Agricultural plastic film mulch in China. Environmental Research Letters. DOI: 10.1088/17489326/9/9/091001.

Liu CA, Jin SL, Zhou LM, Jia Y, Li FM, Xiong YC, Li XG. 2009. Effects of plastic film mulch and tillage on maize productivity and soil parameters. European Journal of Agronomy 31:241-249. DOI: 10.1016/j.eja.2009.08.004.

Liu CA, Zhou LM, Jia JJ, Wang LJ, Si JT, Li X, Pan CC, Siddique KHM, Li FM. 2014b. Maize yield and water balance is affected by nitrogen application in a film-mulching ridge-furrow system in a semiarid region of China. European Journal of Agronomy 52:103-111. DOI: 10.1016/j.eja.2013.10.001.

Lu X, Li Z, Bu Q, Cheng D, Duan W, Sun Z. 2014. Effects of Rainfall Harvesting and Mulching on Corn Yield and Water Use in the Corn Belt of Northeast China. Agronomy Journal 106:2175-2184. DOI: 10.2134/agronj14.0374.

Luo Z, Wang E, Sun OJ. 2010. Can no-tillage stimulate carbon sequestration in agricultural soils? A meta-analysis of paired experiments. Agriculture, Ecosystems and Environment 139:224-231. DOI: 10.1016/j.agee.2010.08.006.

Mbah C, Nwite J. 2010. Physical Properties of an Ultisol under Plastic Film and No-Mulches and Their Effect on the Yield of Maize. World Journal of Agricultural Sciences 6:160-165.

Mensah AK, Frimpong KA. 2018. Biochar and/or Compost Applications Improve Soil Properties, Growth, and Yield of Maize Grown in Acidic Rainforest and Coastal Savannah Soils in Ghana. International Journal of Agronomy 2018. DOI: 10.1155/2018/6837404.

Mohan D, Sarswat A, Ok YS, Pittman CU. 2014. Organic and inorganic contaminants removal from water with biochar, a renewable, low cost and sustainable adsorbent - A critical review. Bioresource Technology 160:191-202. DOI: 10.1016/j.biortech.2014.01.120.

Peerj reviewing PDF | (2020:11:55313:1:1:NEW 1 Jan 2021) 
474

475

476

477

478

479

480

481

482

483

484

485

486

487

488

489

490

491

492

493

494

495

496

497

498

499

500

501

502

503

504

505

506

507

508

509

510

511

512

513

Moher D, Liberati A, Tetzlaff J, Altman DG, Altman D, Antes G, Atkins D, Barbour V, Barrowman N, Berlin JA, Clark J, Clarke M, Cook D, D’Amico R, Deeks JJ, Devereaux PJ, Dickersin K, Egger M, Ernst E, Gøtzsche PC, Grimshaw J, Guyatt G, Higgins J, Ioannidis JPA, Kleijnen J, Lang T, Magrini N, McNamee D, Moja L, Mulrow C, Napoli M, Oxman A, Pham B, Rennie D, Sampson M, Schulz KF, Shekelle PG, Tovey D, Tugwell P. 2009. Preferred reporting items for systematic reviews and meta-analyses: The PRISMA statement. PLoS Medicine 6. DOI: 10.1371/journal.pmed.1000097.

Mondal M, Skalicky M, Garai S, Hossain A, Sarkar S, Banerjee H, Kundu R, Brestic M, Barutcular C, Erman M, El Sabagh A, Laing AM. 2020. Supplementing nitrogen in combination with rhizobium inoculation and soil mulch in peanut (Arachis hypogaea L.) production system: Part II. effect on phenology, growth, yield attributes, pod quality, profitability, and nitrogen use efficiency. Agronomy 10. DOI: 10.3390/agronomy10101513.

Nelissen V, Rütting T, Huygens D, Staelens J, Ruysschaert G, Boeckx P. 2012. Maize biochars accelerate short-term soil nitrogen dynamics in a loamy sand soil. Soil Biology and Biochemistry 55:20-27. DOI: 10.1016/j.soilbio.2012.05.019.

Olsovska K, Kovar M, Brestic M, Zivcak M, Slamka P, Shao HB. 2016. Genotypically identifying wheat mesophyll conductance regulation under progressive drought stress. Frontiers in Plant Science 7:1-14. DOI: 10.3389/fpls.2016.01111.

Pan Y, Pan X, Zi T, Hu Q, Wang J, Han G, Wang J, Pan Z. 2019. Optimal Ridge-Furrow Ratio for Maximum Drought Resilience of Sunflower in Semi-Arid Region of China. Sustainability 11:4047. DOI: 10.3390/su11154047.

Panpatte DG, Jhala YK. 2019. Soil Fertility Management for Sustainable Development. Singapore: Springer Singapore. DOI: 10.1007/978-981-13-5904-0.

Qin SH, Cao L, Zhang JL, Wang D, Wang D. 2016. Soil nutrient availability and microbial properties of a potato field under ridge-furrow and plastic mulch. Arid Land Research and Management 30:181-192. DOI: 10.1080/15324982.2015.1033066.

Qin W, Hu C, Oenema O. 2015. Soil mulching significantly enhances yields and water and nitrogen use efficiencies of maize and wheat: a meta-analysis. Scientific Reports 5:16210. DOI: $10.1038 /$ srep 16210.

Rehman HA, Razzaq R. 2017. Benefits of Biochar on the Agriculture and Environment - A Review. Journal of Environmental Analytical Chemistry 04:3-5. DOI: 10.4172/23802391.1000207.

Ren X, Cai T, Chen X, Zhang P, Jia Z. 2016a. Effect of rainfall concentration with different ridge widths on winter wheat production under semiarid climate. European Journal of Agronomy 77:20-27. DOI: 10.1016/j.eja.2016.03.008.

Ren X, Zhang P, Chen X, Guo J, Jia Z. 2016b. Effect of Different Mulches under Rainfall Concentration System on Corn Production in the Semi-arid Areas of the Loess Plateau. Scientific Reports 6:19019. DOI: 10.1038/srep19019.

Samui I, Skalicky M, Sarkar S, Brahmachari K, Sau S, Ray K, Hossain A, Ghosh A, Kumar M, Bell RW, Mainuddin M, Brestic M, Liu L, Saneoka H, Raza MA, Erman M, Sabagh AEL. 
514

515

516

517

518

519

520

521

522

523

524

525

526

527

528

529

530

531

532

533

534

535

536

537

538

539

540

541

542

543

544

545

546

547

548

549

550

551

552

553

2020. Yield response, nutritional quality, and water productivity of tomato (Solanum lycopersicum L.) are influenced by drip irrigation and straw mulch in the coastal saline ecosystem of Ganges delta, India. Sustainability (Switzerland) 12. DOI: 10.3390/SU12176779.

Shen Q, Ding R, Du T, Tong L, Li S. 2019. Water Use Effectiveness Is Enhanced Using Film Mulch Through Increasing Transpiration and Decreasing Evapotranspiration. Water 11:1153. DOI: 10.3390/w11061153.

Verhulst N, Nelissen V, Jespers N, Haven H, Sayre KD, Raes D, Deckers J, Govaerts B. 2011. Soil water content, maize yield, and its stability as affected by tillage and crop residue management in rainfed semi-arid highlands. Plant and Soil 344:73-85. DOI: 10.1007/s11104-011-0728-8.

Wang L, Coulter JA, Palta JA, Xie J, Luo Z, Li L, Carberry P, Li Q, Deng X. 2019. Mulchinginduced changes in tuber yield and nitrogen use efficiency in potato in China: A metaanalysis. Agronomy 9:1-15. DOI: 10.3390/agronomy9120793.

Wang FX, Feng SY, Hou XY, Kang SZ, Han JJ. 2009. Potato growth with and without plastic mulch in two typical regions of Northern China. Field Crops Research 110:123-129. DOI: 10.1016/j.fcr.2008.07.014.

Xiang Y, Deng Q, Duan H, Guo Y. 2017. Effects of biochar application on root traits: a metaanalysis. GCB Bioenergy 9:1563-1572. DOI: 10.1111/gcbb.12449.

Xiao Q, Zhu L-X, Zhang H-P, Li X-Y, Shen Y-F, Li S-Q. 2016. Soil amendment with biochar increases maize yields in a semi-arid region by improving soil quality and root growth. Crop and Pasture Science 67:495. DOI: 10.1071/CP15351.

Xiaoli C, Pute W, Xining Z, Persaud N. 2013. Effect of Different Mulches on Harvested Rainfall Use Efficiency for Corn (Zea mays L.) in Semi-Arid Regions of Northwest China. Arid Land Research and Management 27:272-285. DOI: 10.1080/15324982.2013.771231.

Yang X, Ali A. 2018. Biochar for soil water conservation and salinization control in arid desert regions. Elsevier Inc. DOI: 10.1016/B978-0-12-811729-3.00009-1.

Ye J, Liu C. 2012. Suitability of Mulch and Ridge-furrow Techniques for Maize across the Precipitation Gradient on the Chinese Loess Plateau. Journal of Agricultural Science 4. DOI: $10.5539 /$ jas.v4n10p182.

Yu Y, Jia H, Zhao C. 2018. Evaluation of the effects of plastic mulching and nitrapyrin on nitrous oxide emissions and economic parameters in an arid agricultural field. Geoderma 324:98-108. DOI: 10.1016/j.geoderma.2018.03.012.

Yu Y-Y, Turner NC, Gong Y-H, Li F-M, Fang C, Ge L-J, Ye J-S. 2018. Benefits and limitations to straw- and plastic-film mulch on maize yield and water use efficiency: A meta-analysis across hydrothermal gradients. European Journal of Agronomy 99:138-147. DOI: 10.1016/j.eja.2018.07.005.

Yu H, Zou W, Chen J, Chen H, Yu Z, Huang J, Tang H, Wei X, Gao B. 2019. Biochar amendment improves crop production in problem soils: A review. Journal of Environmental Management 232:8-21. DOI: 10.1016/j.jenvman.2018.10.117. 
554

555

556

557

558

559

560

561

562

563

564

565

566

567

568

569

570

571

572

573

574

575

576

577

578

579

580

581

582

583

584

585

Zeng X, Zhang Y, Kwong JSW, Zhang C, Li S, Sun F, Niu Y, Du L. 2015. The methodological quality assessment tools for preclinical and clinical studies, systematic review and metaanalysis, and clinical practice guideline: A systematic review. Journal of Evidence-Based Medicine 8:2-10. DOI: 10.1111/jebm.12141.

Zhang P, Wei T, Cai T, Ali S, Han Q, Ren X, Jia Z. 2017. Plastic-film mulching for enhanced water-use efficiency and economic returns from maize fields in semiarid China. Frontiers in Plant Science 8. DOI: 10.3389/fpls.2017.00512.

Zhang F, Zhang W, Qi J, Li FM. 2018. A regional evaluation of plastic film mulching for improving crop yields on the Loess Plateau of China. Agricultural and Forest Meteorology 248:458-468. DOI: 10.1016/j.agrformet.2017.10.030.

Zhang X, Zhao J, Yang L, Kamran M, Xue X, Dong Z, Jia Z, Han Q. 2019. Ridge-furrow mulching system regulates diurnal temperature amplitude and wetting-drying alternation behavior in the soil to promote maize growth and water use in a semiarid region. Field Crops Research 233. DOI: 10.1016/j.fcr.2019.01.009.

Zhao H, Xiong YC, Li FM, Wang RY, Qiang SC, Yao TF, Mo F. 2012. Plastic film mulch for half growing-season maximized WUE and yield of potato via moisture-temperature improvement in a semi-arid agroecosystem. Agricultural Water Management 104:68-78. DOI: 10.1016/j.agwat.2011.11.016.

Zhao Y, Zhai X, Wang Z, Li H, Jiang R, Lee Hill R, Si B, Hao F. 2018. Simulation of soil water and heat flow in ridge cultivation with plastic film mulching system on the Chinese Loess Plateau. Agricultural Water Management 202. DOI: 10.1016/j.agwat.2018.02.017.

Zheng J, Fan J, Zou Y, Chau HW, Zhang F. 2019. Ridge-furrow plastic mulching with a suitable planting density enhances rainwater productivity, grain yield, and the economic benefit of rainfed maize. Journal of Arid Land. DOI: 10.1007/s40333-019-0032-7.

Zhou L-M, Li F-M, Jin S-L, Song Y. 2009. How two ridges and the furrow mulched with plastic film affect soil water, soil temperature, and yield of maize on the semiarid Loess Plateau of China. Field Crops Research 113:41-47. DOI: 10.1016/j.fcr.2009.04.005.

Zribi W, Aragüés R, Medina E, Faci JM. 2015. Efficiency of inorganic and organic mulching materials for soil evaporation control. Soil and Tillage Research 148:40-45. DOI: 10.1016/j.still.2014.12.003.

Peer) reviewing PDF | (2020:11:55313:1:1:NEW 1 Jan 2021) 


\section{Table $\mathbf{1}$ (on next page)}

Study areas, crops and literature sources used in this meta-analysis 
1 Table 1. Study areas, crops and literature sources used in this meta-analysis

\begin{tabular}{|c|c|c|c|c|c|}
\hline Province & Study areas & $\begin{array}{c}\text { Geo-coordinate }(\mathrm{N}, \mathbf{E}, \\
\text { m a.s.l) }\end{array}$ & Crop & Reference & NOS \\
\hline \multirow{11}{*}{ Gansu } & Qingyang & $35^{\circ} 42^{\prime}, 107^{\circ} 20^{\prime}$ & \multirow[b]{2}{*}{ Wheat } & Gao et al., 2014 & 9 \\
\hline & $\begin{array}{l}\text { Tangjiabu, } \\
\text { Dingxi }\end{array}$ & $35^{\circ} 57^{\prime}, 104^{\circ} 59^{\prime}, 1970$ & & Li et al., 2004 & 8 \\
\hline & \multirow{4}{*}{ Dingxi } & $35^{\circ} 33^{\prime}, 104^{\circ} 35^{\prime}, 1896.7$ & \multirow{5}{*}{ Potato } & Zhao et al., 2012 & 7 \\
\hline & & $35^{\circ} 33^{\prime}, 104^{\circ} 35^{\prime}, 1896.7$ & & Zhao et al., 2014 & 7 \\
\hline & & $35^{\circ} 33^{\prime}, 104^{\circ} 35^{\prime}, 1874$ & & Qin et al., 2014 & 8 \\
\hline & & $36^{\circ} 02^{\prime}, 104^{\circ} 25^{\prime}, 2400$ & & Zhou et al., 2015 & 6 \\
\hline & \multirow{3}{*}{$\begin{array}{l}\text { Zhonglianchua } \\
\text { n, Yuzhong }\end{array}$} & $36^{\circ} 02^{\prime}, 104^{\circ} 25^{\prime}, 2400$ & & Liu and Siddique, 2015 & 8 \\
\hline & & $36^{\circ} 2^{\prime}, 104^{\circ} 25^{\prime}, 2400$ & \multirow{2}{*}{ Maize } & Eldoma et al., 2016 & 8 \\
\hline & & $36^{\circ} 02^{\prime}, 104^{\circ} 25^{\prime}, 2400$ & & Zhou et al., 2009 & 9 \\
\hline & Gaolan & $36^{\circ} 2^{\prime}, 103^{\circ} 7^{\prime}, 1780$ & \multirow{4}{*}{ Potato } & \multirow{2}{*}{ Wang et al., 2005} & 6 \\
\hline & Yuzhong & $35^{\circ} 9^{\prime}, 104^{\circ} 1^{\prime}, 1800$ & & & 6 \\
\hline \multirow{2}{*}{ Ningxia } & \multirow{2}{*}{ Pengyang } & $35^{\circ} 51^{\prime}, 106^{\circ} 48^{\prime}, 1658$ & & Wu et al., 2017 & 7 \\
\hline & & $106^{\circ} 45^{\prime}, 35^{\circ} 79^{\prime}, 1800$ & & Zhang et al., 2017 & 8 \\
\hline \multirow{7}{*}{ Shaanxi } & \multirow{5}{*}{ Changwu } & $34^{\circ} 59^{\prime}, 107^{\circ} 38^{\prime}, 1220$ & \multirow{4}{*}{ Maize } & Lu et al., 2020 & 8 \\
\hline & & $35^{\circ} 14^{\prime}, 107^{\circ} 41^{\prime}, 1206$ & & Zhang et al., 2011 & 8 \\
\hline & & $\begin{array}{c}35^{\circ} 14^{\prime}, 107^{\circ} 41^{\prime}, 1200- \\
1206\end{array}$ & & Lin et al., 2019 & 6 \\
\hline & & $35^{\circ} 14^{\prime}, 107^{\circ} 42^{\prime}, /$ & & Qin et al., 2018 & 6 \\
\hline & & $35^{\circ} 12^{\prime}, 107^{\circ} 45^{\prime}, 12000$ & Wheat & He et al., 2016 & 9 \\
\hline & \multirow{2}{*}{ Heyang } & $35^{\circ} 15^{\prime}, 110^{\circ} 18^{\prime}, 910$ & \multirow{4}{*}{ Maize } & Li et al., 2012 & 9 \\
\hline & & $35^{\circ} 15^{\prime}, 110^{\circ} 18^{\prime}, 910$ & & HAN et al., 2013 & 8 \\
\hline \multirow[b]{2}{*}{ Shanxi } & \multirow[b]{2}{*}{ Shouyang } & $37^{\circ} 54^{\prime}, 113^{\circ} 09^{\prime}, 1273$ & & Gaimei et al., 2017 & 7 \\
\hline & & $\begin{array}{c}37^{\circ} 45^{\prime} 58^{\prime \prime}, 113^{\circ} 12^{\prime} 9^{\prime \prime} \\
1202\end{array}$ & & Gong et al., 2017 & 7 \\
\hline
\end{tabular}


Table 2 (on next page)

Categorization of data within the selected publications 
Table 2. Categorization of data within the selected publications

\begin{tabular}{|c|c|c|c|c|c|c|c|c|}
\hline $\begin{array}{l}\text { Annual mean } \\
\text { precipitation }\end{array}$ & $\begin{array}{l}\text { Annual air } \\
\text { temperature }\end{array}$ & $\begin{array}{c}\text { Organic C } \\
\text { content }\end{array}$ & $\begin{array}{c}\text { Soil bulk } \\
\text { density }(0-20 \\
\mathrm{cm})\end{array}$ & $\begin{array}{l}\text { Soil texture }(0-20 \\
\qquad \mathrm{cm})\end{array}$ & $\mathrm{pH}$ & $\begin{array}{c}\text { Soil } \\
\text { available N }\end{array}$ & $\begin{array}{c}\text { Soil } \\
\text { available P }\end{array}$ & $\begin{array}{c}\text { Soil } \\
\text { available K }\end{array}$ \\
\hline$<400 \mathrm{~mm}$ & $<9{ }^{\circ} \mathrm{C}$ & $<9 \mathrm{~g} / \mathrm{kg}$ & $\begin{array}{r}<1.3 \\
\mathrm{~g} \mathrm{~cm}^{-3}\end{array}$ & $\begin{array}{l}\text { Light: sandy and } \\
\text { sandy loam soils }\end{array}$ & $\begin{array}{l}\text { Very acidic: } \\
\mathrm{pH}<5\end{array}$ & $\begin{array}{c}<50 \\
\mathrm{mg} \mathrm{kg}^{-1}\end{array}$ & $\begin{array}{c}<20 \\
\mathrm{mg} \mathrm{kg}^{-1}\end{array}$ & $\begin{array}{c}<150 \\
\mathrm{mg} \mathrm{kg}^{-1}\end{array}$ \\
\hline$>400 \mathrm{~mm}$ & $>9{ }^{\circ} \mathrm{C}$ & $>9 \mathrm{~g} / \mathrm{kg}$ & $\begin{array}{l}>1.3 \\
\mathrm{~g} \mathrm{~cm}^{-3}\end{array}$ & $\begin{array}{l}\text { Medium: loamy } \\
\text { sand and loam } \\
\text { soils }\end{array}$ & $\begin{array}{l}\text { Acidic: } \\
\text { pH 5-6 }\end{array}$ & $\begin{array}{c}>50 \\
\mathrm{mg} \mathrm{kg}\end{array}$ & $\begin{array}{c}>20 \\
\mathrm{mg} \mathrm{kg}^{-1}\end{array}$ & $\begin{array}{c}>150 \\
\mathrm{mg} \mathrm{kg}\end{array}$ \\
\hline & & & & $\begin{array}{l}\text { Heavy: clay loam, } \\
\text { silty clay, and clay } \\
\text { soils }\end{array}$ & $\begin{array}{c}\text { Neutral: } \\
\text { pH 6-7 } \\
\text { Slightly } \\
\text { alkaline: } \\
>7\end{array}$ & & & \\
\hline \multicolumn{9}{|c|}{ 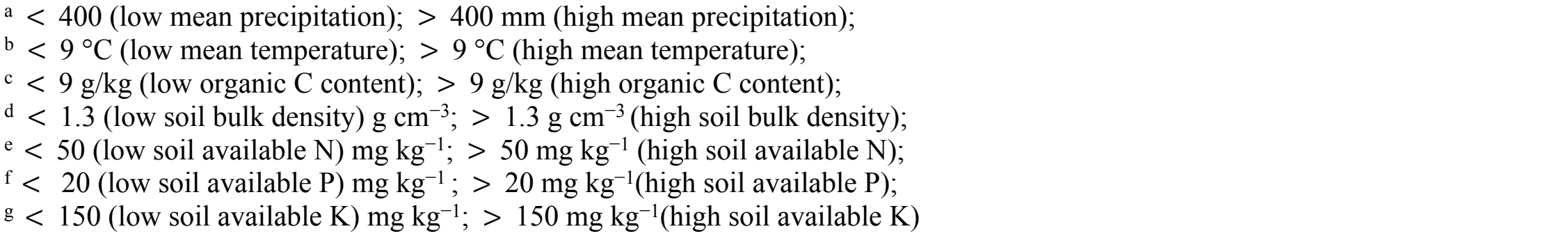 } \\
\hline
\end{tabular}




\section{Table 3(on next page)}

Variations in yield, evapotranspiration (ET), and water use efficiency (WUE) of wheat, maize, and potato under plastic film and no-mulching application. 
1 Table 3. Variations in yield, evapotranspiration (ET), and water use efficiency (WUE) of wheat, maize, and potato under plastic film

2 and no-mulching application.

\begin{tabular}{|c|c|c|c|c|c|c|c|c|c|c|c|c|c|c|}
\hline \multirow[b]{2}{*}{ Treatments } & \multirow[b]{2}{*}{ Parameters } & \multirow[b]{2}{*}{ Variable } & \multicolumn{4}{|c|}{ Yield } & \multicolumn{4}{|c|}{ ET } & \multicolumn{4}{|c|}{ WUE } \\
\hline & & & $\mathbf{n}$ & Mean & Range & $\mathrm{CV}$ & $\mathbf{n}$ & Mean & Range & $\mathrm{CV}$ & $\mathbf{n}$ & Mean & Range & $\mathrm{CV}$ \\
\hline \multirow[t]{11}{*}{ Plastic film } & Location & Gansu & 10 & 8821.6 & $2162.3-45882$ & 151 & 7 & 279 & $215.4-386.5$ & 22 & 7 & 33.3 & $0.8-129.95$ & 138 \\
\hline & & Ningxia & 2 & 12926 & $12779.3-13072.5$ & 1.6 & 2 & 435 & $375.5-494.3$ & 19 & 2 & 30.4 & $26.8-34.1$ & 17 \\
\hline & & Shaanxi & 7 & 9313.1 & $4931.8-13079.3$ & 32.6 & 3 & 367 & $300-409.5$ & 16 & 3 & 25.5 & $22-32.1$ & 22.2 \\
\hline & & Shanxi & 2 & 11408 & $11290-11526.7$ & 1.47 & 2 & 391 & $345.4-435.7$ & 16 & 2 & 14.9 & $3.4-26.5$ & 110 \\
\hline & Crop type & Maize & 13 & 9813.4 & $2420-13079.3$ & 32.8 & 8 & 392 & $300-494.3$ & 15 & 7 & 23.9 & $3.4-34.1$ & 42.3 \\
\hline & & Wheat & 2 & 3547.1 & $2162.3-4931.8$ & 55.2 & 1 & 273 & - & - & 1 & 0.75 & - & - \\
\hline & & Potato & 6 & 11235 & $2359.3-45882$ & 152 & 5 & 259 & $215.4-333.7$ & 18 & 6 & 38.7 & $6.4-129.95$ & 123 \\
\hline & Rainfall & $<400$ & 8 & 9532.4 & $2359.3-45882$ & 156 & 6 & 281 & $215.4-386.5$ & 23 & 6 & 38.7 & $6.4-129.96$ & 123 \\
\hline & & $>400$ & 13 & 9678.2 & $2162.3-13079.3$ & 35.3 & 8 & 378 & $272.5-494.3$ & 19 & 8 & 21 & $0.8-34.1$ & 59.2 \\
\hline & Temperature & $<9$ & 13 & 9776.2 & $2162.3-45882$ & 119 & 11 & 328 & $215.4-494.3$ & 27 & 11 & 29.4 & $0.75-129.95$ & 125 \\
\hline & & $>9$ & 8 & 9660.8 & $4931.8-13079.3$ & 28.7 & 3 & 367 & $300-409.5$ & 16 & 3 & 25.5 & $22-32.07$ & 22.2 \\
\hline \multirow[t]{11}{*}{ No mulching } & Location & Gansu & 10 & 5021.3 & $353-27385.5$ & 162 & 7 & 320 & $253.5-461.1$ & 26 & 7 & 19.7 & $0.6-79.6$ & 144 \\
\hline & & Ningxia & 2 & 10755 & $9978.3-11532$ & 10.2 & 2 & 437 & $400-473.99$ & 12 & 2 & 24.6 & $24.2-24.9$ & 1.93 \\
\hline & & Shaanxi & 7 & 8249.1 & $4650.4-10422.3$ & 27.5 & 3 & 365 & $289.7-404$ & 18 & 3 & 22 & $19.5-26$ & 16.2 \\
\hline & & Shanxi & 2 & 10116 & $9988.3-10243.3$ & 1.78 & 2 & 407 & $380.6-433.3$ & 9.2 & 2 & 13.2 & $2.7-23.7$ & 113 \\
\hline & Crop type & Maize & 13 & 7896.5 & $353-11532$ & 44 & 8 & 398 & $289.7-473.99$ & 13 & 8 & 17.8 & $0.9-26$ & 57 \\
\hline & & Wheat & 2 & 2639.8 & $629.1-4650.4$ & 108 & 1 & 273 & - & - & 1 & 0.56 & - & - \\
\hline & & Potato & 6 & 6960.7 & $833-27385.5$ & 147 & 5 & 313 & $253.5-461.1$ & 29 & 5 & 27.4 & $3.6-79.6$ & 113 \\
\hline & Rainfall & $<400$ & 8 & 5537.7 & $353-27385.5$ & 163 & 6 & 328 & $253.5-461.1$ & 27 & 6 & 22.9 & $0.9-79.6$ & 129 \\
\hline & & $>400$ & 13 & 8107.4 & $629.1-11532$ & 38.7 & 8 & 382 & $273.1-473.99$ & 18 & 8 & 17.8 & $0.6-26$ & 57.5 \\
\hline & Temperature & $<9$ & 9 & 7069.7 & $353-27385.5$ & 122 & 11 & 357 & $253.5-474$ & 24 & 11 & 19.4 & $0.56-79.6$ & 117 \\
\hline & & $>9$ & 8 & 7590.7 & $4650.4-10422.3$ & 28.3 & 3 & 365 & $289.7-404$ & 18 & 3 & 22 & $19.5-26.03$ & 16.2 \\
\hline
\end{tabular}




\section{Table 4 (on next page)}

Mean, range, and coefficient of variation (CV) of yield, evapotranspiration (ET), and water use efficiency (WUE) of wheat, maize, and potato under plastic film mulching and no mulching in different locations and precipitations in northern China 
1 Table 4. Mean, range, and coefficient of variation (CV) of yield, evapotranspiration (ET), and water use efficiency (WUE) of wheat, 2 maize, and potato under plastic film mulching and no mulching in different locations and precipitations in northern China

\begin{tabular}{|c|c|c|c|c|c|c|c|c|c|c|c|c|c|c|}
\hline \multirow[b]{2}{*}{ Treatments } & \multirow[b]{2}{*}{ Parameters } & \multirow[b]{2}{*}{ Variables } & \multicolumn{4}{|c|}{ Yield } & \multicolumn{4}{|c|}{ ET } & \multicolumn{4}{|c|}{ WUE } \\
\hline & & & $\mathbf{n}$ & Mean & Range & $\mathrm{CV}$ & $\mathbf{n}$ & Mean & Range & $\mathrm{CV}$ & $\mathbf{n}$ & Mean & Range & $\mathrm{CV}$ \\
\hline \multirow[t]{14}{*}{ Plastic film } & Organic $\mathrm{C}$ & $<9$ & 8 & 10504 & $2162.3-45882$ & 140 & 6 & 334 & $215.4-494.3$ & 29 & 6 & 32.9 & $0.75-129.95$ & 147 \\
\hline & content & $>9$ & 7 & 11369 & $9260-13079.3$ & 13.2 & 4 & 403 & $375.5-435.7$ & 6.4 & 4 & 28.8 & $22.5-34.07$ & 18.3 \\
\hline & Bulk density & $<1.3$ & 8 & 11190 & $2162.3-45882$ & 129 & 6 & 327 & $230.9-435.7$ & 23 & 5 & 47.5 & $6.35-129.95$ & 103 \\
\hline & & $>1.3$ & 9 & 9399.7 & $4255.75-13072.5$ & 36.6 & 6 & 379 & $259.2-494.3$ & 20 & 6 & 22.5 & $3.36-34.07$ & 50.4 \\
\hline & $\mathrm{pH}$ & $>7$ & 11 & 11729 & $2420-45882$ & 102 & 7 & 381 & $215.4-494.3$ & 23 & 7 & 36.5 & $6.35-129.95$ & 115 \\
\hline & Soil texture & Light & 5 & 16667 & $2549.8-45882$ & 101 & 4 & 340 & $215.4-435.7$ & 27 & 4 & 50.5 & $11.7-129.95$ & 106 \\
\hline & & Medium & 5 & 7571.2 & $2162.3-13079.3$ & 57.8 & 3 & 254 & $230.9-272.5$ & 8.4 & 3 & 23.4 & $0.75-52.85$ & 114 \\
\hline & & Heavy & 10 & 7938.6 & $2359.3-13072.5$ & 50.1 & 6 & 388 & $300-494.3$ & 17 & 6 & 18.8 & $3.36-32.07$ & 60.8 \\
\hline & $\mathrm{N}$ & $<50$ & 4 & 7221.3 & $2420-13079.3$ & 76.8 & 2 & 301 & $215.4-386.5$ & 40 & 2 & 8.98 & $6.35-11.62$ & 41.5 \\
\hline & & $>50$ & 6 & 9935.7 & $2162.3-13072.5$ & 41.7 & 5 & 388 & $272.5-494.3$ & 20 & 5 & 23.2 & $0.75-34.07$ & 57.5 \\
\hline & & $<20$ & 8 & 9775.4 & $2420-13079.3$ & 40.9 & 4 & 423 & $375.5-494.3$ & 13 & 4 & 23.4 & $6.35-34.07$ & 50.9 \\
\hline & $\mathrm{P}$ & $>20$ & 4 & 7636.7 & $2162.3-12545.3$ & 57.5 & 4 & 343 & $272.5-409.5$ & 20 & 4 & 19.3 & $0.75-32.07$ & 68.4 \\
\hline & & $<150$ & 7 & 9788.8 & $4931.8-13079.3$ & 31.2 & 4 & 384 & $300-435.7$ & 15 & 5 & 20.8 & $0.75-32.07$ & 57.3 \\
\hline & $\mathrm{K}$ & $>150$ & 4 & 20382 & $9794.5-45882$ & 83.7 & 3 & 401 & $333.7-494.3$ & 21 & 3 & 63.6 & $26.8-129.95$ & 90.5 \\
\hline \multirow[t]{13}{*}{ No mulching } & Organic $\mathrm{C}$ & $<9$ & 8 & 6676.5 & $353-27385.5$ & 137 & 6 & 374 & $273.1-473.99$ & 23 & 6 & 21.5 & $0.56-79.6$ & 140 \\
\hline & & $>9$ & 7 & 8891 & $5282-10422.3$ & 20.6 & 4 & 410 & $400-433$ & 3.9 & 4 & 23.5 & $19.5-26.03$ & 12.1 \\
\hline & Bulk density & $<1.3$ & 8 & 7499.1 & $353-27385.5$ & 118 & 6 & 332 & $253.5-433.3$ & 22 & 5 & 31.1 & $0.85-79.6$ & 94.3 \\
\hline & & $>1.3$ & 9 & 7215.8 & $2184.5-11532$ & 49.2 & 6 & 386 & $253.8-473.99$ & 19 & 6 & 18.1 & $2.7-26.03$ & 51.3 \\
\hline & $\mathrm{pH}$ & $>7$ & 11 & 8213.5 & $353-27385.5$ & 91.4 & 7 & 417 & $344.1-473.99$ & 10 & 7 & 25.4 & $0.85-79.6$ & 102 \\
\hline & Soil texture & Light & 5 & 11622 & $833-27385.5$ & 83.1 & 4 & 410 & $344.1-461.1$ & 12 & 4 & 33 & $3.6-79.6$ & 98.9 \\
\hline & & Medium & 5 & 4872.7 & $629-8848.5$ & 66.2 & 3 & 260 & $253.5-273.1$ & 4.3 & 3 & 14.3 & $0.56-30.9$ & 108 \\
\hline & & Heavy & 10 & 6206.8 & $353-11532$ & 65.2 & 6 & 392 & $289.7-473.99$ & 15 & 6 & 15.6 & $0.85-26.03$ & 70.5 \\
\hline & $\mathrm{N}$ & $<50$ & 4 & 4989.9 & $353-9925.2$ & 102 & 2 & 431 & $400-461.05$ & 10 & 2 & 2.23 & $0.85-3.6$ & 87.4 \\
\hline & & $>50$ & 6 & 7606 & $629.1-11532$ & 53.6 & 5 & 390 & $273.1-473.99$ & 19 & 5 & 19 & $0.56-26.03$ & 55.8 \\
\hline & & $<20$ & 8 & 7569.7 & $353-11532$ & 50 & 4 & 427 & $400-473.99$ & 8.2 & 4 & 18.4 & $0.85-24.9$ & 63.6 \\
\hline & $\mathrm{P}$ & $>20$ & 4 & 6172.1 & $629.1-10422.3$ & 67.1 & 4 & 342 & $273.1-404$ & 21 & 4 & 16.6 & $0.56-26.03$ & 66.7 \\
\hline & $\mathrm{K}$ & $<150$ & 7 & 8210.3 & $4650.4-10422.3$ & 27.2 & 4 & 382 & $289.67-433.3$ & 17 & 5 & 18 & $0.56-26.03$ & 56.1 \\
\hline
\end{tabular}




\section{Table 5 (on next page)}

Mean, range, and coefficient of variation (CV) of yield of maize for plastic film mulched ridge-furrow and no mulching in Shanxi and Shaanxi provinces in China 
1 Table 5. Mean, range, and coefficient of variation (CV) of yield of maize for plastic film 2 mulched ridge-furrow and no mulching in Shanxi and Shaanxi provinces in China

\begin{tabular}{lccccc}
\hline \multicolumn{1}{c}{ Treatments } & Crop & n & Mean & Range & CV \\
\hline $\begin{array}{l}\text { Plastic film }+ \\
\text { biochar mulching }\end{array}$ & Maize & 3 & 11.913 & $10.43-14.7$ & 20.3 \\
No mulching & Maize & 3 & 9.6967 & $9.11-9.99$ & 5.24 \\
\hline
\end{tabular}

3 
Table 6(on next page)

Heterogeneity analysis on yield, evapotranspiration (ET), and water use efficiency (WUE) of wheat, maize, and potato under plastic film and no-mulching treatments using random-effects models. 
1 Table 6. Heterogeneity analysis on yield, evapotranspiration (ET), and water use efficiency 2 (WUE) of wheat, maize, and potato under plastic film and no-mulching treatments using 3 random-effects models.

\begin{tabular}{|c|c|c|c|c|c|c|c|}
\hline \multirow[b]{2}{*}{ Items } & \multirow[b]{2}{*}{ Parameters } & \multirow[b]{2}{*}{ Categories } & \multirow[b]{2}{*}{$\mathbf{n}$} & \multicolumn{4}{|c|}{ Heterogeneity } \\
\hline & & & & df & $\mathbf{P}$ & Chi2 & I2 (\%) \\
\hline \multirow{9}{*}{ Yield } & \multirow{4}{*}{ Location } & Gansu & 22 & 9 & 1 & 0.68 & 0 \\
\hline & & Ningxia & 5 & 1 & 0.37 & 0.82 & 0 \\
\hline & & Shaanxi & 27 & 6 & 0.59 & 4.67 & 0 \\
\hline & & Shanxi & 5 & 1 & 0.9 & 0.01 & 0 \\
\hline & \multirow{3}{*}{ Crop type } & Maize & 39 & 12 & 0.2 & 15.72 & 24 \\
\hline & & Wheat & 7 & 1 & 0.79 & 0.07 & 0 \\
\hline & & Potato & 14 & 5 & 0.99 & 0.44 & 0 \\
\hline & \multirow{2}{*}{ Rainfall } & $<400$ & 18 & 7 & 1 & 0.55 & 0 \\
\hline & & $>400$ & 43 & 13 & 0.92 & 6.66 & 0 \\
\hline \multirow{9}{*}{ ET } & \multirow{4}{*}{ Location } & Gansu & 14 & 6 & 1 & 0.3 & 0 \\
\hline & & Ningxia & 5 & 1 & 0.53 & 0.4 & 0 \\
\hline & & Shaanxi & 10 & 2 & 0.71 & 0.68 & 0 \\
\hline & & Shanxi & 6 & 1 & 0.35 & 0.87 & 0 \\
\hline & \multirow{3}{*}{ Crop type } & Maize & 23 & 7 & 0.88 & 3.05 & 0 \\
\hline & & Wheat & 2 & & - & - & - \\
\hline & & Potato & 10 & 4 & 0.99 & 0.22 & 0 \\
\hline & \multirow{2}{*}{ Rainfall } & $<400$ & 12 & 5 & 1 & 0.29 & 0 \\
\hline & & $>400$ & 23 & 7 & 0.89 & 2.99 & 0 \\
\hline \multirow{9}{*}{ WUE } & \multirow{4}{*}{ Location } & Gansu & 14 & 6 & 1 & 0.37 & 0 \\
\hline & & Ningxia & 5 & 1 & 0.19 & 1.71 & 41 \\
\hline & & Shaanxi & 10 & 2 & 0.33 & 2.19 & 9 \\
\hline & & Shanxi & 6 & 1 & 0.5 & 0.46 & 0 \\
\hline & \multirow{3}{*}{ Crop type } & Maize & 23 & 7 & 0.69 & 4.79 & 0 \\
\hline & & Wheat & 2 & - & - & - & - \\
\hline & & Potato & 10 & 4 & 0.99 & 0.35 & 0 \\
\hline & \multirow{2}{*}{ Rainfall } & $<400$ & 12 & 5 & 1 & 0.37 & 0 \\
\hline & & $>400$ & 23 & 7 & 0.68 & 4.87 & 0 \\
\hline
\end{tabular}

4 
Table 7 (on next page)

Heterogeneity analysis on yield, evapotranspiration (ET), and water use efficiency (WUE) of wheat, maize, and potato under plastic film and no-mulching treatments using random-effects models. 
1 Table 7. Heterogeneity analysis on yield, evapotranspiration (ET), and water use efficiency 2 (WUE) of wheat, maize, and potato under plastic film and no-mulching treatments using 3 random-effects models.

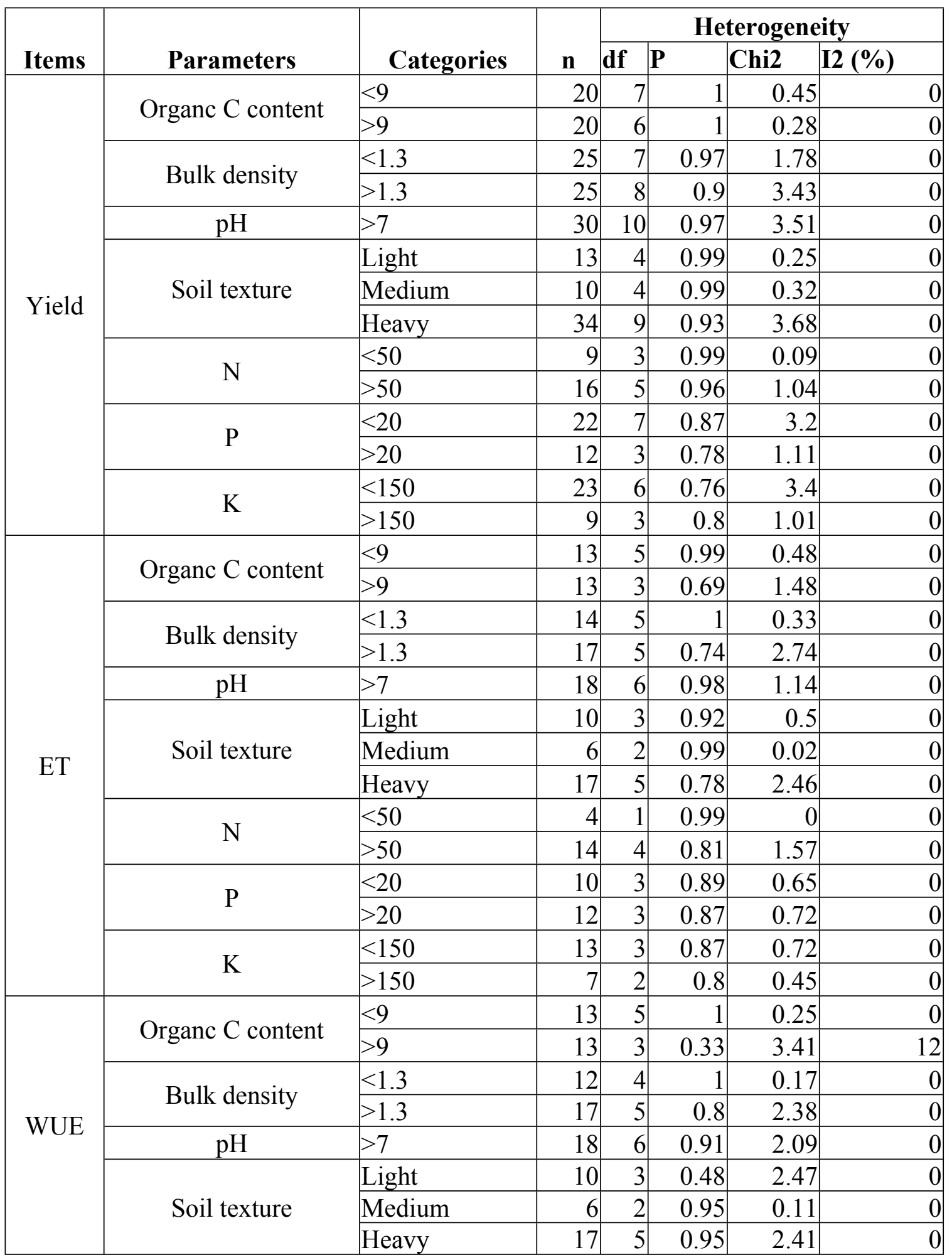




\begin{tabular}{|c|l|l|r|r|r|r|r|}
\hline \multirow{2}{*}{$\mathrm{N}$} & $<50$ & 4 & 1 & 0.86 & 0 & 0 \\
\cline { 2 - 7 } & $>50$ & 14 & 4 & 0.62 & 2.66 & 0 \\
\cline { 2 - 7 } & $<20$ & 10 & 3 & 0.49 & 2.43 & 0 \\
\cline { 2 - 7 } & $>20$ & 12 & 3 & 0.52 & 2.28 & 0 \\
\cline { 2 - 7 } & $<150$ & 15 & 4 & 0.62 & 2.61 & 0 \\
\cline { 2 - 7 } & $>150$ & 2 & 0.42 & 1.75 & 0 \\
\hline \multirow{2}{*}{$\mathrm{K}$} & $>150$ &
\end{tabular}

4 
Figure 1

Flowchart of literature identification, and screening for use in this study. Adapted from PRISMA (Moher et al., 2009) 


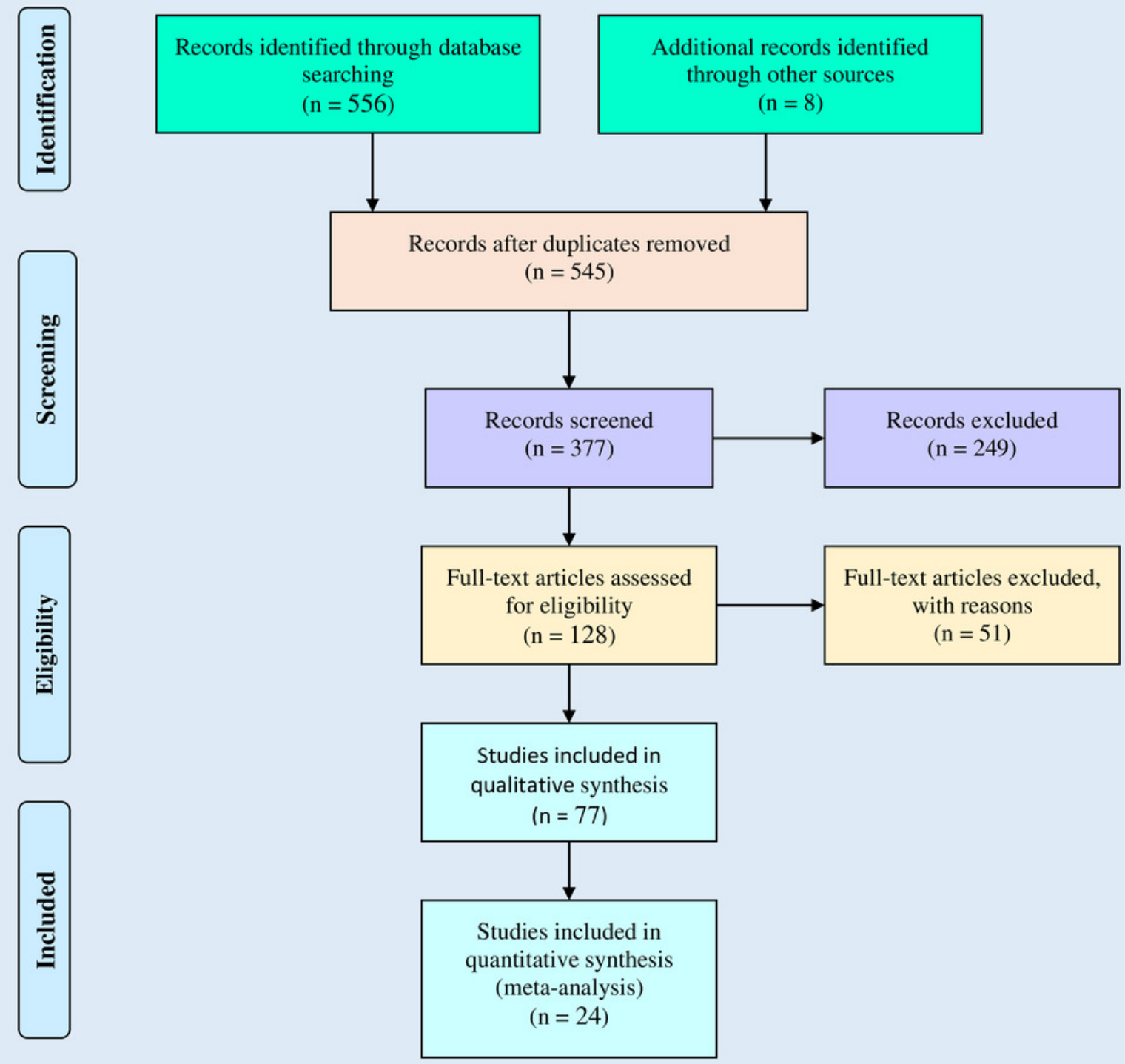

Figure 1. Flowchart of literature identification, and screening for use in this study. Adapted from PRISMA (Moher et al., 2009). 
Figure 2

Experimental locations from the peer-reviewed publications for the meta-analysis. ArcGIS 10.6 software (ESRI, Redlands, California) was used to produce the map.

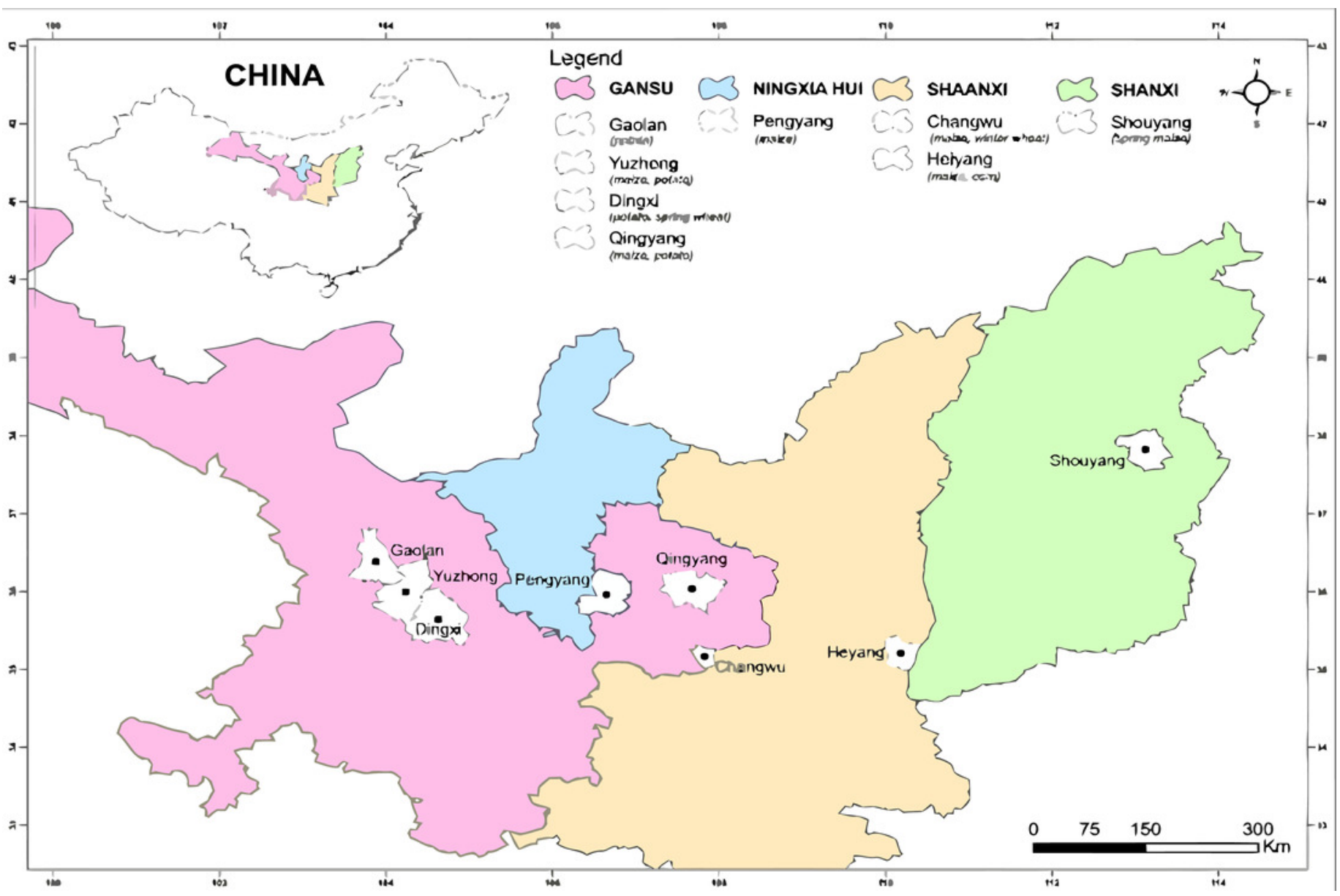


Figure 3

A. Odds ratios of crop yields in different locations and climate. B. Odds ratios of yield in different soil properties. The error bars signify $95 \%$ confidence intervals, and the values above the bars indicate the number of observations $(n)$.
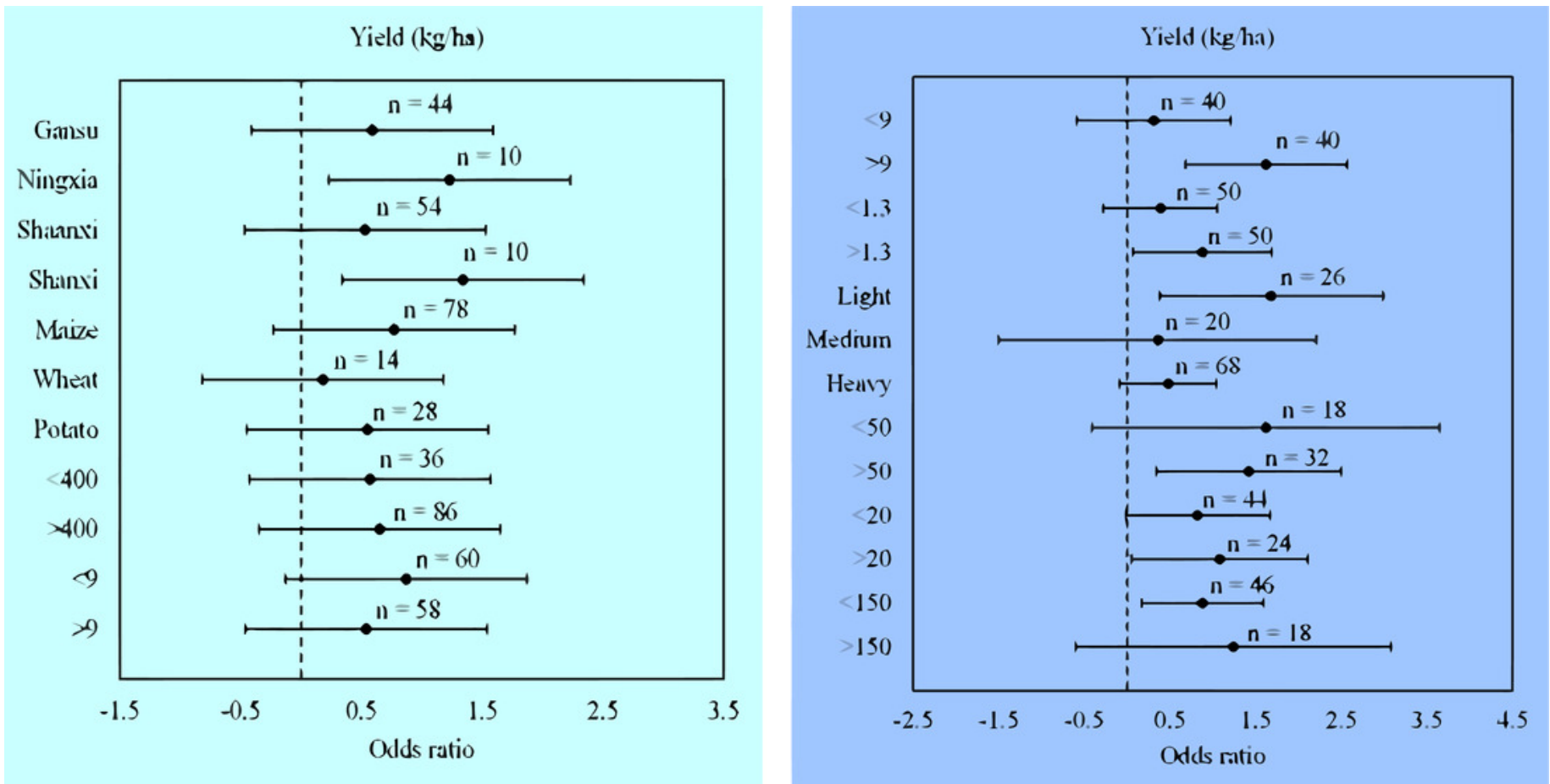
Figure 4

A. Odds ratios of evapotranspiration (ET) in different locations and climate. B. Odds ratios of evapotranspiration (ET) in different soil properties. The error bars signify $95 \%$ confidence intervals, and the values above the bars indicate the number of obs
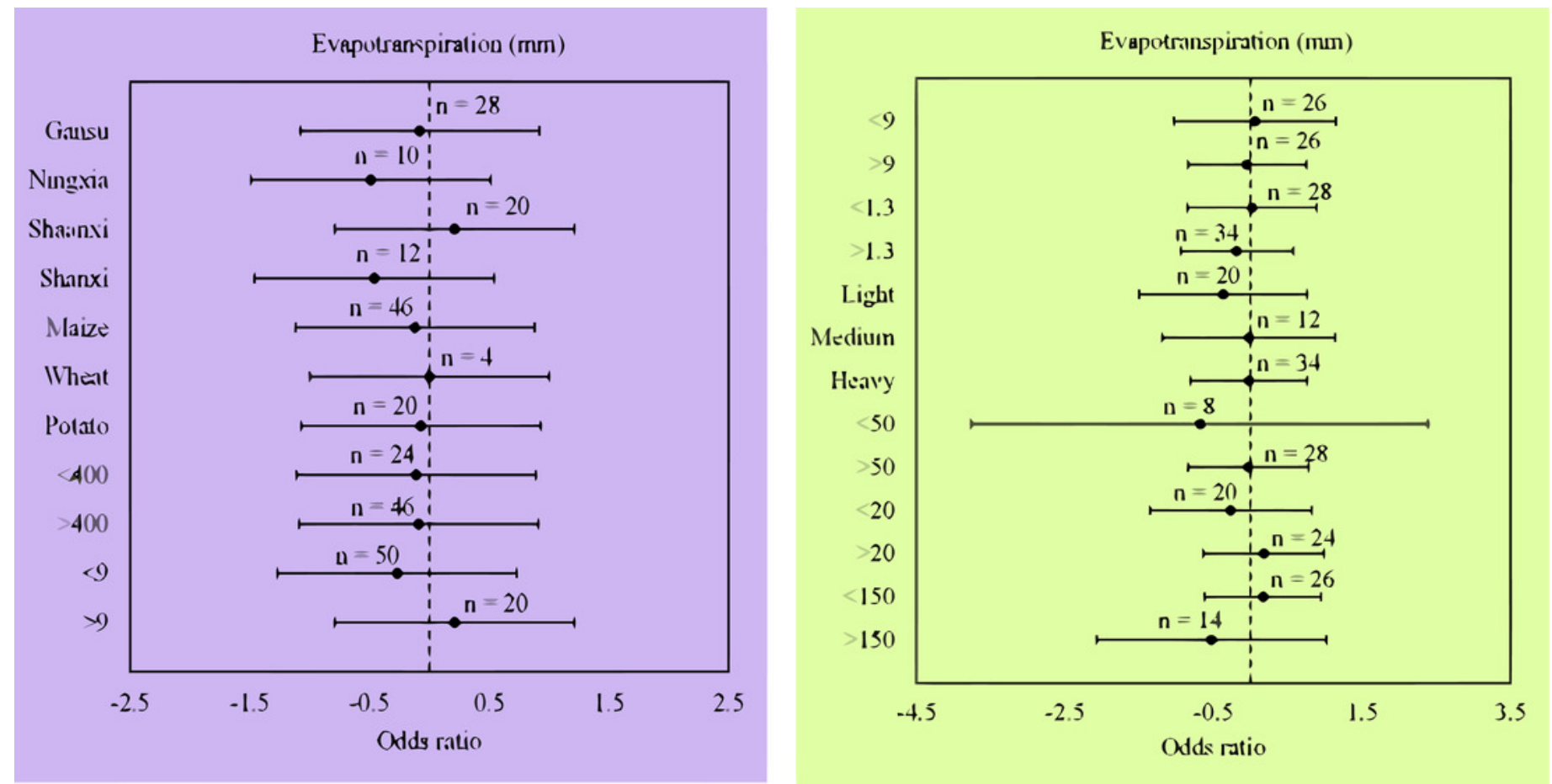


\section{Figure 5}

A. The odds ratios of water use efficiency (WUE) for plastic film relative to no mulching in different locations and climate. B. The odds ratios of water use efficiency (WUE) for plastic film relative to no mulching in different soil properties. The error
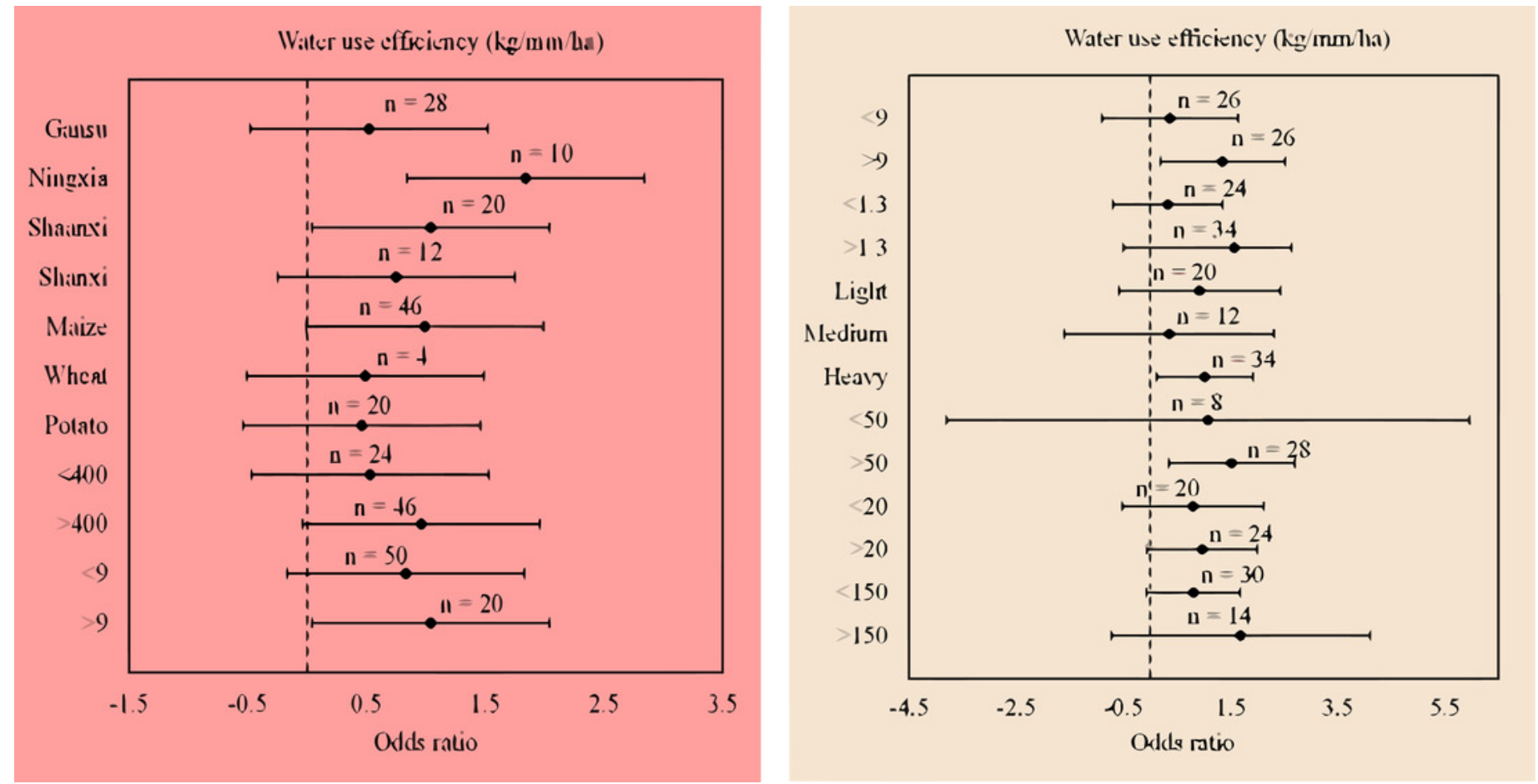